Article

\title{
Synthesis, Structural, and Cytotoxic Properties of New Water-Soluble Copper(II) Complexes Based on 2,9-Dimethyl-1,10-Phenanthroline and Their One Derivative Containing 1,3,5-Triaza-7- Phosphaadamantane-7-Oxide
}

\author{
Ewelina I. Śliwa ${ }^{1}$, Urszula Śliwińska-Hill ${ }^{2}$, Barbara Bażanów ${ }^{3}{ }^{\circledR}$, Miłosz Siczek ${ }^{1}$, Julia Kłak ${ }^{1}(\mathbb{D}$ \\ and Piotr Smoleński ${ }^{1, *(1)}$ \\ 1 Faculty of Chemistry, University of Wrocław, ul. F. Joliot-Curie 14, 50-383 Wrocław, Poland; \\ ewelina.sliwa@chem.uni.wroc.pl (E.I.Ś.); milosz.siczek@chem.uni.wroc.pl (M.S.); \\ julia.klak@chem.uni.wroc.pl (J.K.) \\ 2 Department of Analytical Chemistry, Faculty of Pharmacy, Wroclaw Medical University, Borowska 211 A, \\ 50-566 Wrocław, Poland; urszula.sliwinska-hill@umed.wroc.pl \\ 3 Department of Pathology, Wrocław University of Environmental and Life Sciences, ul. Norwida 31, \\ 50-375 Wrocław, Poland; barbara.bazanow@upwr.edu.pl \\ * Correspondence: piotr.smolenski@chem.uni.wroc.pl; Tel.: +48-713-757-225
}

Received: 31 December 2019; Accepted: 5 February 2020; Published: 8 February 2020

\begin{abstract}
A series of water-soluble copper(II) complexes based on 2,9-dimethyl-1,10-phenanthroline (dmphen) and mixed-ligands, containing PTA=O (1,3,5-triaza-7-phosphaadamantane-7-oxide) have been synthesized and fully characterized. Two types of complexes have been obtained, monocationic $\left[\mathrm{Cu}\left(\mathrm{NO}_{3}\right)(\mathrm{O}-\mathrm{PTA}=\mathrm{O})(\mathrm{dmphen})\right]\left[\mathrm{PF}_{6}\right](\mathbf{1}),\left[\mathrm{Cu}(\mathrm{Cl})(\mathrm{dmphen})_{2}\right]\left[\mathrm{PF}_{6}\right](2)$, and neutral $\left[\mathrm{Cu}\left(\mathrm{NO}_{3}\right)_{2}(\mathrm{dmphen})\right]$ (3). The solid-state structures of all complexes have been determined by single-crystal X-ray diffraction. Magnetic studies for the complex 1-3 indicated a very weak antiferromagnetic interaction between copper(II) ions in crystal lattice. Complexes were successfully evaluated for their cytotoxic activities on the normal human dermal fibroblast (NHDF) cell line and the antitumor activity using the human lung carcinoma (A549), epithelioid cervix carcinoma (HeLa), colon (LoVo), and breast adenocarcinoma (MCF-7) cell lines. Complexes $\mathbf{1}$ and $\mathbf{3}$ revealed lower toxicity to NHDF than A549 and HeLa cells, meanwhile compound 2 appeared to be more toxic to NHDF cell line in comparison to all cancer lines. Additionally, interactions between the complexes and human apo-transferrin (apo-Tf) using fluorescence and circular dichroism (CD) spectroscopy were also investigated. All compounds interacted with apo-transferrin, causing same changes of the protein conformation. Electrostatic interactions dominate in the $\mathbf{1} / \mathbf{2}$-apo- Tf systems and hydrophobic and ionic interactions in the case of 3.
\end{abstract}

Keywords: copper(II); discrete complexes; 2,9-dimethyl-1,10-phenanthroline; 1,3,5-triaza-7phospaadamantane-7-oxide; antitumor activity; cytotoxic activity

\section{Introduction}

Coordination chemistry of copper compounds has been an important subject of intensive investigations by researchers for many years [1-3]. Coordination polymers or discrete complexes constructed of copper metal ions and organic ligands/linkers have been investigated for the design of a new generation for luminescent [4-7], magnetic [8], catalytic [9-12], host-guests [13], and biological [14-19] properties. Thus, recently, there is great attention on the coordination chemistry 
of copper(I/II) complexes, due to their structural and physicochemical properties, in particular biological. On the one hand, an important role of copper in various biological processes, such as photosynthesis and dinitrogen metabolism as well as oxidative stress protection, etc., was reported by many scientists $[14,15]$. On the other hand, recent biological studies demonstrated that copper(I/II) coordination compounds represent various biomedical applications [16] that contain antifungal [17] and antibacterial [18] activities. Moreover, some of these complexes show also a relatively high activity as antiviral, anticancer, and antiproliferative agents and lower toxicity than cisplatin [15,17-19].

However, copper(II) simple compounds have a relatively low human toxicity in comparison to other transition metal ions [20]. Toxicity of such complexes is connected with coordinated organic ligands, which are required properties for therapeutic agents. Additionally, many metal complexes used as bioactive agents are sparingly soluble in water media, limiting their applications in these systems. Combining of metal salts, organic ligands, and auxiliary counterions with appropriate properties may result not only in obtaining complexes with broader spectra of bioactivity but also sufficient aqua-solubility. In this regard, the air-stable and water-soluble aminophosphine 1,3,5-triaza-7-phosphaadamantane (PTA) and 1,3,5-triaza-7-phosphaadamantane-7-oxide (PTA=O) (Scheme 1) represent a good alternative to conventional phosphine and aminophosphine ligands. In the last decades the coordination chemistry of PTA and PTA=O has seen a pronounced development justified by the search for water-soluble and stable transition metal complexes [21-23]. Currently, several examples of $\mathrm{PTA}=\mathrm{O}$ coordination modes are known, where a tetrapodal ligand is connected to a metal center in the O- [24-26], N- [24,27,28], ON- [24,25], ONN- [10,29], NNN- [30], or ONNNmodes [29,31], achieving either discrete metallic units or polymeric compounds [32].

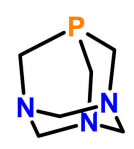

PTA

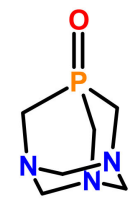

PTA $=0$

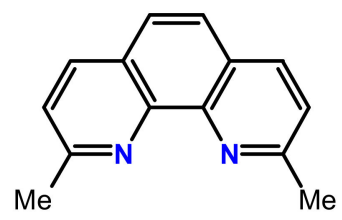

dmphen

Scheme 1. Structural formulas of the ligands.

Among the biorelevant N-donor ligands suitable to afford new bioactive metal complexes, polypyridines represent a good choice due to a recognizable influence on a large variety of biological functions [33-37]. In fact, the aromatic $N, N$-ligands such as 2,9-dimethyl-1,10-phenanthroline (dmphen, Scheme 1) have been a subject of intense research owing to their documented action in diverse biological systems [38]. A series of $\mathrm{Cu}(\mathrm{I})$-dmphen complexes stabilized by tertiary phosphines and other $\mathrm{Cu}$ (II)-dmphen coordination compounds have been also reported, but their poor solubility in polar solvents eventually prevented the application of these compounds as bioactive materials [38,39]. In particular, some of us have reported a number of water-soluble copper(I/II)-PTA-cage coordination networks $[10,40-44]$ as well as a discrete complexes [32,40-43,45-48], which were evaluated successfully for their magnetic [10,43,45], catalytic [10,44], and luminescent properties [40,42,44,48].

By further extending these studies from polypyridine-type $N, N$-ligand - 2,9-dimethyl-1,10phenanthroline (dmphen), we now report the synthesis, characterization, and biological activity of the three discrete copper(II) complexes $\left[\mathrm{Cu}\left(\mathrm{NO}_{3}\right)(\mathrm{PTA}=\mathrm{O})(\mathrm{dmphen})\right]\left[\mathrm{PF}_{6}\right](\mathbf{1}),\left[\mathrm{Cu}(\mathrm{Cl})(\mathrm{dmphen})_{2}\right]\left[\mathrm{PF}_{6}\right](\mathbf{2})$, and $\left(\mathrm{Cu}\left(\mathrm{NO}_{3}\right)_{2}(\mathrm{dmphen})\right)(3)$. Due to appropriate hydrosolubility, compounds were evaluated for their cytotoxic and antitumor activity in aqua media. In addition, the interactions between the complexes and human apo-transferrin were investigated by circular dichroism (CD) and fluorescence spectroscopy. 


\section{Results and Discussion}

\subsection{Synthesis and Characterization}

The reaction of $\mathrm{Cu}\left(\mathrm{NO}_{3}\right)_{2}$ with a stoichiometric amount of PTA=O, in EtOH solution under reflux conditions, followed by the addition of a stoichiometric amount of dmphen $(\mathrm{Cu}: \mathrm{PTA}=\mathrm{O}$ : dmphen molar ratios of 1:1:1), led to $\left[\mathrm{Cu}\left(\mathrm{NO}_{3}\right)(\mathrm{PTA}=\mathrm{O})(\mathrm{dmphen})\right]\left[\mathrm{PF}_{6}\right](\mathbf{1})$ discrete coordination compound (Scheme 2). Treatment of $\mathrm{CuCl}_{2}$ with dmphen in the presence of $\mathrm{KPF}_{6}$ in a Cu:dmphen: $\mathrm{KPF}_{6}$ molar ratio $(1: 1: 1)$ under the same conditions afforded $\left[\mathrm{Cu}(\mathrm{Cl})(\mathrm{dmphen})_{2}\right]\left[\mathrm{PF}_{6}\right](2)$ complex (Scheme 2), whereas the use of $\mathrm{Cu}\left(\mathrm{NO}_{3}\right)_{2}$ salt with a stoichiometric amount of dmphen in MeCN under reflux conditions and molar ratio (1:1) gave rise to the formation of $\left[\mathrm{Cu}\left(\mathrm{NO}_{3}\right)_{2}(\mathrm{dmphen})\right] \cdot \mathrm{MeCN}(3)$. Compounds 1-3 were isolated as air stable, green microcrystalline solids in ca. $36-85 \%$ yields based on appropriate copper salt, and characterized by IR spectroscopy, elemental analyses, and single-crystal X-ray diffraction. Although during the preparation of this manuscript the X-ray structure of 2 was published but described by us as one-pot reaction that was faster and yielded a cleaner product than the previously published method [49].

Compounds 1-3 were soluble in organic polar solvents, such as DMSO or $\mathrm{MeOH}$, and sparingly soluble in middle polar solvents, like $\mathrm{CH}_{2} \mathrm{Cl}_{2}$, whereas they were insoluble in apolar solvents, like $\mathrm{Et}_{2} \mathrm{O}$, toluene, and alkanes. Moreover, all compounds were soluble in water, with the $\mathrm{S}_{25}{ }^{\circ} \mathrm{C}$ values 3.8 , 2.5 , and $2.9 \mathrm{mg} \mathrm{mL}^{-1}$ for $\mathbf{1}, \mathbf{2}$, and 3, respectively. Their water solutions were relatively stable in air (see experimental section). The IR spectra of 1-3 exhibited absorptions due to the typical vibrations of dmphen, and, additionally, for 1, PTA $=\mathrm{O}$ ligands with characteristic band at $1158 \mathrm{~cm}^{-1}$ due to $v(\mathrm{P}=\mathrm{O})$ vibrations [21-23,50-53]. Additionally, the IR spectra also showed the characteristic strong and broad absorptions for $\mathrm{NO}_{3}{ }^{-}$(for 1 and 3), and $\mathrm{PF}_{6}{ }^{-}$anions (for $\mathbf{1}$ and 2), centered at 1365-1445 and $732-792 \mathrm{~cm}^{-1}$, respectively [53].

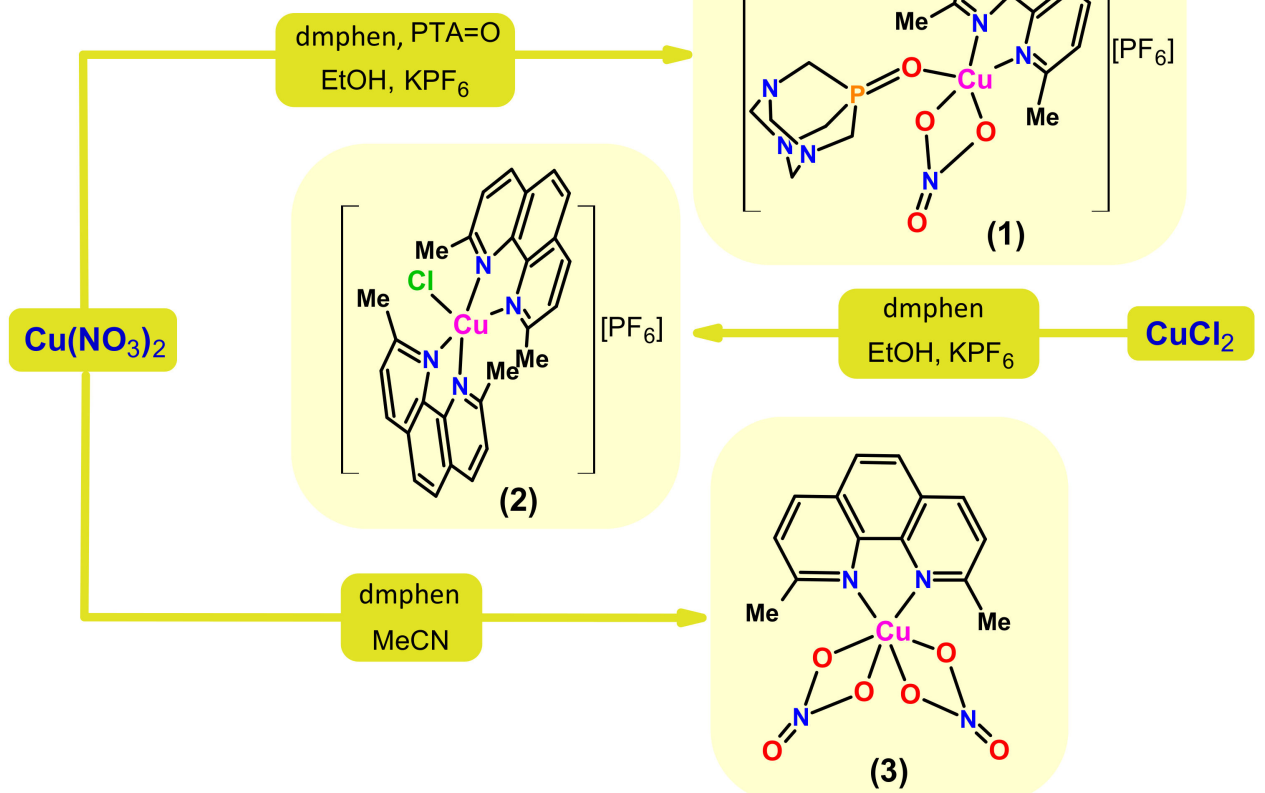

Scheme 2. Schematic representation of the synthesis and structural formulae for 1-3.

\subsection{Crystal Structures}

Compound 1 crystallized in monoclinic space group $P 21 / n$ and was composed of a $\left[\mathrm{Cu}(\mathrm{PTA}=\mathrm{O})(\mathrm{dmphen})\left(\mathrm{NO}_{3}\right)\right]^{+}$unit and $\mathrm{PF}_{6}{ }^{-}$anion (Figure 1, Table 1). Compound 1 represented 
the first example of a $\mathrm{Cu}$-dmphen five-coordinate complex with unusual bidentate coordination of $\mathrm{NO}_{3}{ }^{-}$anion. The coordination geometry of $\mathrm{Cu}$ can best be described as distorted square-pyramidal with $\tau=0.17$ (where $\tau$ is the Addison parameter describing the distortion around coordination geometry, defined as $\tau=(\beta-\alpha) / 60$ for $\alpha(\mathrm{O} 13-\mathrm{Cu}-\mathrm{N} 11)=102.90(4) \AA$ and $\beta(\mathrm{O} 12-\mathrm{Cu}-\mathrm{N} 11)=$ 112.83(4) $\AA$ ) [54]. The coordination sites of $\mathrm{Cu}$ were occupied by two nitrogen atoms from dmphen (N11 and N21), one oxygen atom from PTA=O (O12), and two oxygen atoms from $\mathrm{NO}_{3}{ }^{-}$(O13 and $\left.\mathrm{O} 23\right)$. $\mathrm{PF}_{6}{ }^{-}$anion was disordered over two positions. The $\mathrm{Cu}-\mathrm{N}$ bonds were 1.995(1) $\AA(\mathrm{Cu}-\mathrm{N} 11)$ and 1.972(1) $\AA(\mathrm{Cu}-\mathrm{N} 21)$ and were a similar to those observed in other $\mathrm{Cu}-\mathrm{N}-\mathrm{dmphen}$ five-coordinate compounds (in a range of 1.988-2.039 $\AA$ ), for example, $\left.\left(\mathrm{Cu} \text { (dmphen) }\left(\mathrm{CH}_{3} \mathrm{OH}\right)\right)_{2}\left(\mu-\mathrm{C}_{2} \mathrm{O}_{4}\right)\right)\left(\mathrm{ClO}_{4}\right)_{2}[55]$ and $\left(\mathrm{CuCl}_{2}(\right.$ dmphen $\left.)\left(\mathrm{H}_{2} \mathrm{O}\right)\right)$ [56] complexes with $\mathrm{Cu}-\mathrm{O}$ distances $1.970 \AA$ and $1.996 \AA$, respectively. The $\mathrm{Cu}-\mathrm{O}_{\mathrm{NO}}$ bond distances were 2.028(1) $\AA$ ( $\left.\mathrm{Cu}-\mathrm{O} 13\right)$ and 2.083(1) $\AA(\mathrm{Cu}-\mathrm{O} 23)$ and were lower in comparison to values observed in other $\mathrm{Cu}-\mathrm{NO}_{3}$ compounds, for example $\left(\mathrm{Cu}\left(\mathrm{C}_{7} \mathrm{H}_{5} \mathrm{O}_{3}\right)\left(\mathrm{NO}_{3}\right)\left(\mathrm{C}_{14} \mathrm{H}_{12} \mathrm{~N}_{2}\right)\right)$ compound with $\mathrm{Cu}-\mathrm{O}$ distances 2.292(3) $\AA$ [57].

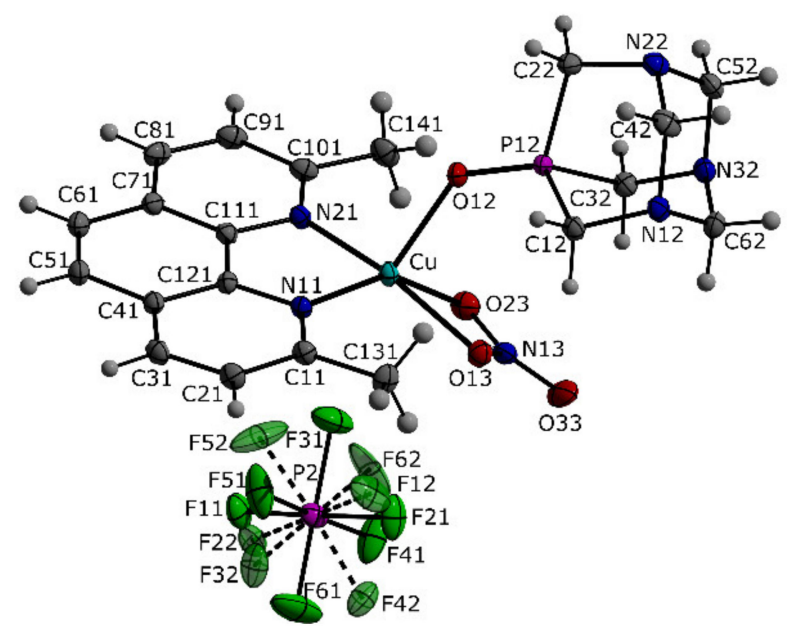

Figure 1. Molecular structure of compound 1. Ellipsoids shown at the 50\% probability. Color code: Grey, carbon; blue, nitrogen; red, oxygen; violet, phosphor; green, fluoride; cyan, copper; light grey, hydrogen. Selected bond lengths $[\AA]$ and angles [ $\left.{ }^{\circ}\right]$ : Cu-N21, 1.972(1); Cu-N11, 1.995(1); Cu-O12, 2.102(1); Cu-O13, 2.028(1); Cu-O23, 2.083(1); P12-O12,1.506(1); N11-Cu-N21, 84.66(5); Cu-N11-C11, 130.80(9); Cu-O12-P12, 134.23(7); N11-Cu-O12, 112.83(4); N11-Cu-O13, 102.90(5); N11-Cu-O23, 148.04(5); N11-Cu-O12, 100.93(5); N21-Cu-O13, 161.17(5); N21-Cu-O23, 101.54(5); N21-Cu-O13, 92.08(4); O12-Cu-O23, 96.90(5); O13-Cu-O23, 63.04(5).

The compound 3 crystallized in a monoclinic space group I2/a, comprising a $\mathrm{Cu}(\mathrm{dmphen})\left(\mathrm{NO}_{3}\right)_{3}$ unit with one solvent molecule (Figure 2, Table 1) and represented the second example of a Cu-dmphen six-coordinate complex with unusual bidentate coordination of $\mathrm{NO}_{3}{ }^{-}$anion [58]. The coordination sphere of the $\mathrm{Cu}$ atom was occupied by two $\mathrm{N}$ atoms from $\mathrm{dmphen}$ and four $\mathrm{O}$ atoms from two nitrate anions, yielding a strongly distorted $\mathrm{CuN}_{2} \mathrm{O}_{4}$ octahedral environment. The $\mathrm{Cu}-\mathrm{N}$ bond distance was 1.989(2) $\AA(\mathrm{Cu}-\mathrm{N} 11)$ and was similar to those observed in other $\mathrm{Cu}-\mathrm{N}-\mathrm{dmphen}$ compounds [59]. The $\mathrm{Cu}-\mathrm{O}$ bond distances were 2.421(2) $\AA$ ( $\mathrm{Cu}-\mathrm{O} 12)$ and 2.006(2) $\AA(\mathrm{Cu}-\mathrm{O} 22)$ and were comparable to $\mathrm{Cu}-\mathrm{O}$ bond distances in $\mathrm{Cu}-\mathrm{NO}_{3}$ compounds $[60,61]$.

The crystal structure of $\mathbf{1}$ was stabilized by $\pi-\pi$ stacking interactions between antiparallel aromatic rings, with interplanar distances of 3.556 (2) $\AA$ (Figure 3A) [62]. In the crystal structure of 3, molecules created 1D chains through $\pi-\pi$ stacking interaction (3.562(2) $\AA$ ) between dmphen ligands (Figure 3B) [62]. A channel between the chains was occupied by acetonitrile solvent molecules. 


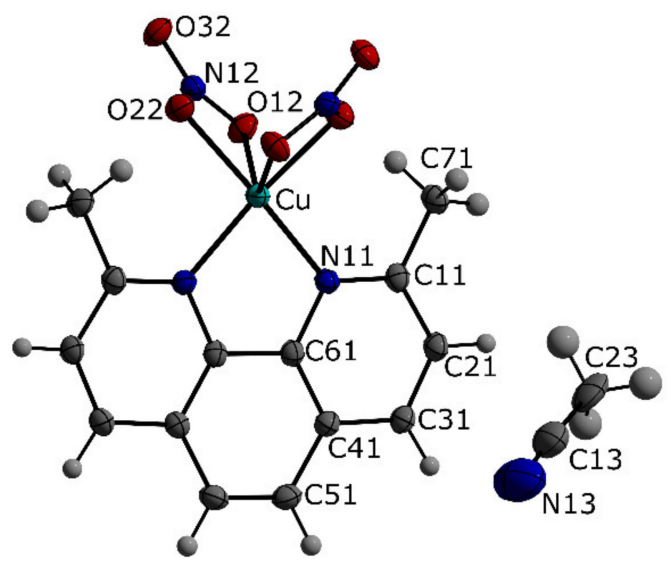

Figure 2. Molecular structure of compound 3 with atom labelling scheme. Ellipsoids shown at the 50\% probability. Color code: Grey, carbon; blue, nitrogen; red, oxygen; cyan, copper; light grey, hydrogen. Selected bond lengths $(\AA)$ and angles $\left({ }^{\circ}\right)$ : Cu-O12, 2.42; Cu-O22, 2.006; Cu-N11, 1.989; O12-Cu-O22, 57.62; O12-Cu-N11, 96.32; O12-Cu-N11, 119.68; O12-Cu-O12, 131.58; O12-Cu-O22, 87.13; O22-Cu-N11, 152.35; O22-Cu-N11, 99.67; O22-Cu-O22, 88.88; N11-Cu-N11, 84.89; N11-Cu-O22, 99.67.

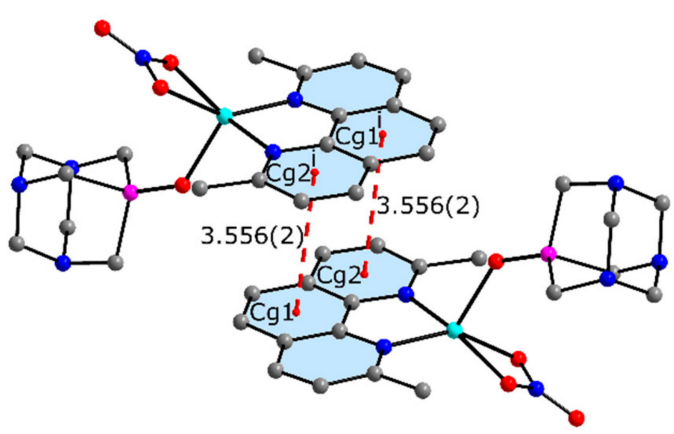

A)

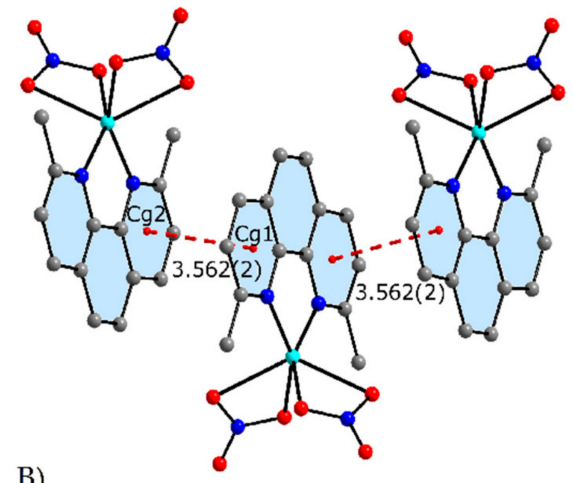

B)

Figure 3. The $\pi-\pi$ stacking interactions represented in red dashed line in compound $\mathbf{1}(\mathbf{A})$ and compound 3 (B).

Table 1. Crystal data and structure refinement details.

\begin{tabular}{|c|c|c|}
\hline Formula Unit & {$\left[\mathrm{C}_{20} \mathrm{H}_{24} \mathrm{CuN}{ }_{6} \mathrm{O}_{4} \mathrm{P}\right]\left[\mathrm{PF}_{6}\right](1)$} & {$\left[\mathrm{C}_{14} \mathrm{H}_{12} \mathrm{CuN}_{4} \mathrm{O}_{6}\right]\left[\mathrm{C}_{2} \mathrm{H}_{3} \mathrm{~N}\right]$ (3) } \\
\hline Formula weight & 651.93 & 436.87 \\
\hline Crystal system & Monoclinic & Monoclinic \\
\hline Space group & $P 2_{1} / n$ & $I 2 / a$ \\
\hline$a(\AA)$ & 10.094(3) & $10.500(7)$ \\
\hline$b(\AA)$ & $17.125(4)$ & $14.480(8)$ \\
\hline$c(\AA)$ & $14.330(4)$ & $12.426(9)$ \\
\hline$\beta\left(^{\circ}\right)$ & $95.44(3)$ & $106.71(5)$ \\
\hline Z & 4 & 4 \\
\hline Volume $\left(\AA^{3}\right)$ & $2465.9(12)$ & $1809(2)$ \\
\hline$T(K)$ & $100(2)$ & $100(2)$ \\
\hline$D_{\mathrm{c}}\left(\mathrm{g} \mathrm{cm}^{-3}\right)$ & 1.756 & 1.604 \\
\hline$\mu\left(\mathrm{mm}^{-1}\right)$ & 1.103 & 1.253 \\
\hline$\theta_{\max }, \theta_{\min }\left({ }^{\circ}\right)$ & $36.95,3.50$ & $28.69,3.58$ \\
\hline Rfls. measure, independent & 39426,11361 & 6557,2183 \\
\hline $\mathrm{R}_{\mathrm{int}}$ & 0.0539 & 0.0574 \\
\hline $\mathrm{R}_{1}{ }^{\mathrm{a}}, \mathrm{wR}_{2}{ }^{\mathrm{b}}[I>2 \sigma(I)]$ & $0.0442,0.1195$ & $0.0530,0.1365$ \\
\hline $\mathrm{R}_{1}, \mathrm{wR}_{2}$ (all data) & $0.0526,0.1268$ & $0.0604,0.1548$ \\
\hline
\end{tabular}

${ }^{a} \mathrm{R} 1=\Sigma|| F_{\mathrm{o}}|-| F_{\mathrm{c}}|/ \Sigma| F_{\mathrm{o}} \mid{ }^{b} \mathrm{wR} 2=\left[\Sigma\left[w\left(F_{\mathrm{o}}{ }^{2}-F_{\mathrm{c}}{ }^{2}\right)^{2}\right] / \Sigma\left[w\left(F_{\mathrm{o}}{ }^{2}\right)^{2}\right]\right]^{1 / 2}$ 


\subsection{Magnetic Properties}

The magnetic properties of 1-3 were investigated over the temperature range of 1.8-300 K. Plots of magnetic susceptibility $\chi_{m} T$ product vs. $T$ ( $\chi_{m}$ is the molar magnetic susceptibility per one $\mathrm{Cu}$ (II) ion) are given in Figure 4 . For 1-3, $\chi_{m} T$ was essentially constant $\left(\sim 0.4 \mathrm{~cm}^{3} \mathrm{~mol}^{-1} \mathrm{~K}\right)$ in the whole temperature range. It was consistent with one unpaired electron in magnetically diluted copper(II) complexes [63]. Only a slight decrease of the value $\chi_{m} T$ in the low-temperature range (below $10 \mathrm{~K}$ ) was caused by occurrence of weak antiferromagnetic interactions in the crystal lattice.

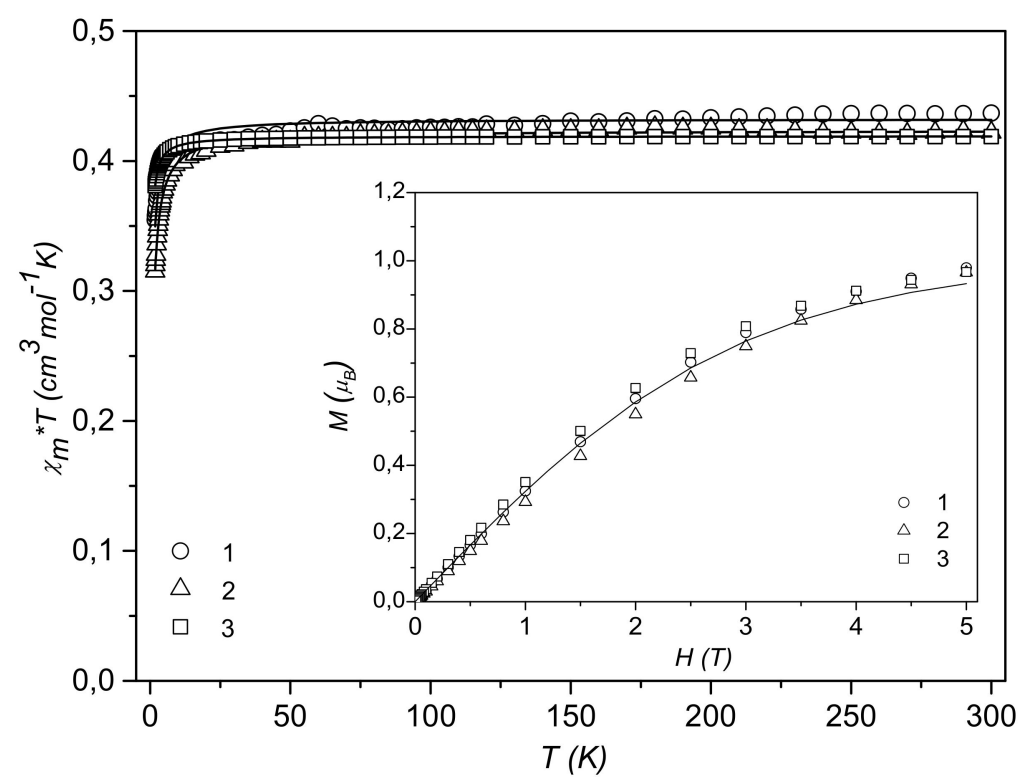

Figure 4. Temperature dependences of experimental $\chi_{m} T$ vs. $T$ ( $\chi_{\mathrm{m}}$ per one $\mathrm{Cu}^{\mathrm{II}}$ atom) for 1-3. The solid lines are the calculated curves derived from Equations (1) and (2). The inset shows field dependences of the magnetization ( $M$ per one $\mathrm{Cu}^{\mathrm{II}}$ atom) at $2 \mathrm{~K}$ for $1-3$. The solid line is the Brillouin function curve for one uncoupled spin with $S=1 / 2$ and $g=2.0$.

The variation of the magnetization $(M)$ with respect to the field $(H)$, at $2 \mathrm{~K}$, also confirmed the nature of the ground state in 1-3 (Figure 4, see inset). As the magnetic field increased, the $M$ vs. $H$ curves are linear in the whole field range and indicate values of magnetization close to $1 \mu_{\mathrm{B}}$ at 5 T. The magnetization curves for $\mathbf{1}-\mathbf{3}$ were reproduced by the equation $M=g \beta S N B_{S}(x)\left(\mathrm{S}=1 \cdot \mathrm{S}_{\mathrm{Cu}}\right)$, where $B_{S}(x)$ is the Brillouin function and $x=g \beta H / k T$ [63]. The experimental values closely followed the Brillouin function for one uncoupled spin with $S=1 / 2$ and confirmed our previous assumption.

From the magnetic point of view, 1, 2, and 3 were considered as mononuclear compounds. In such situations the magnetic data were fitted using the susceptibility equation for $S=1 / 2$ (Equation (1)). To elucidate the significance of exchange between copper(II) ions in the crystal lattice, a molecular field correction term was also included (Equations (1) and (2)) [63,64].

$$
\begin{aligned}
& \chi_{M}=\frac{N \beta^{2} g^{2}}{3 k T} S(S+1) \\
& \chi_{M}^{c o r r}=\frac{\chi_{M}}{1-\frac{2 z J^{\prime}}{N \beta^{2} g^{2}} \cdot \chi_{M}}
\end{aligned}
$$

where $z J^{\prime}$ is the intermolecular exchange parameter, $z$ is the number of the nearest neighbors, and the others have their usual meaning. A least-squares fitting of the experimental data led to the following values: $z J^{\prime}=-0.51(1) \mathrm{cm}^{-1}$ and $\mathrm{g}=2.10(1)\left(\mathrm{R}=3.47 \times 10^{-5}\right)$ for $1, z J^{\prime}=-0.79(1) \mathrm{cm}^{-1}$ and $\mathrm{g}=2.12(1)$ $\left(\mathrm{R}=2.52 \times 10^{-5}\right)$ for 2 , and $z J^{\prime}=-0.45(1) \mathrm{cm}^{-1}$ and $\mathrm{g}=2.15(1)\left(\mathrm{R}=6.15 \times 10^{-5}\right)$ for 3 , as indicated 
by the solid curves in Figure 4. The calculated curves reproduced the magnetic data very well in the whole temperature range (Figure 4 ). The criterion used in determination of the best fit was based on minimization of the sum of squares of the deviation: $R=\Sigma\left(\chi_{\exp } T-\chi_{\text {calc }} T\right)^{2} / \Sigma\left(\chi_{\exp } T\right)^{2}$. Small $z J^{\prime}$ exchange parameters (below $1 \mathrm{~cm}^{-1}$ ) were consistent with the crystal structures of $1-3$. Since the intermolecular $\mathrm{Cu}$ … Cu distances in all complexes were all rather long, it was to be expected that the coupling between electrons of the copper(II) ions in the system were weak. This fact was expected in mononuclear magnetically diluted $\mathrm{Cu}$ (II) compounds [65-68].

The EPR spectra of solid samples 1, 2, and 3 recorded in the X-band at room temperature and $77 \mathrm{~K}$ were essentially similar and additionally confirmed the properties detected by the direct magnetic measurements. The EPR spectra of 1-3 resembled monomeric copper(II) species with poorly resolved hyperfine features and $g_{\|}>g_{\perp}>g_{e}$. The spectral features were characteristic of a distorted square-planar geometry and $\mathrm{a} \mathrm{dx}^{2}{ }^{2} \mathrm{y}^{2}$ ground state for the copper(II) center [69-73]. It was in fairly good agreement with the copper(II) geometries obtained from the crystal structures.

\subsection{Cytotoxic Assays}

On the one hand, toxicity levels of 1-3 on NHDF cells were investigated, which reflected normal cells of a body, and on the other hand, the ability of these compounds to kill the human lung (A549), breast (MCF7), colon (LoVo), and cervical (HeLa) cancer cells. These results of in vitro cytotoxicity tests are demonstrated in Table 2.

Table 2. $\mathrm{IC}_{50}$ values $(\mu \mathrm{M})$ of the tested complexes (1-3), $\mathrm{Cu}\left(\mathrm{NO}_{3}\right)_{2}$, free ligands, and cisplatin.

\begin{tabular}{cccccccc}
\hline Cell Line & $\mathbf{1}$ & $\mathbf{2}$ & $\mathbf{3}$ & $\mathbf{C u}\left(\mathbf{N O}_{3}\right)_{\mathbf{2}}$ & $\mathbf{P T A}=\mathbf{O}$ & Dmphen & Cisplatin \\
\hline NHDF & $0.57 \pm 0.08$ & $0.23 \pm 0.03$ & $1.72 \pm 0.25$ & $310 \pm 47$ & nd & nd & $16.6 \pm 2.1[74]$ \\
A549 & $0.29 \pm 0.01$ & $0.28 \pm 0.04$ & $0.43 \pm 0.06$ & $155 \pm 23$ & nd & nd & $33.3 \pm 4.2[74]$ \\
HeLa & $1.12 \pm 0.16$ & $1.13 \pm 0.17$ & $0.43 \pm 0.06$ & $19.1 \pm 2.9$ & nd & $720 \pm 108$ & $16.6 \pm 3.1[74]$ \\
MCF7 & $0.57 \pm 0.08$ & $0.57 \pm 0.08$ & $3.45 \pm 0.51$ & $155 \pm 23$ & nd & nd & $33.3 \pm 4.2[74]$ \\
LoVo & $0.57 \pm 0.08$ & $1.13 \pm 0.17$ & $1.72 \pm 0.25$ & $38.8 \pm 5.8$ & nd & $360 \pm 54$ & $9.12 \pm 0.005[75]$ \\
\hline \multicolumn{7}{c}{ IC -half maximal inhibitory concentration; nd = not detectable. }
\end{tabular}

Complexes 1 and 3 revealed lower toxicity to normal human cell line $(0.57$ and $1.72 \mu \mathrm{M})$ than A549 cell $(0.29$ and $0.43 \mu \mathrm{M})$, respectively. Moreover, 3 showed similar activity against HeLa cell line $(0.43 \mu \mathrm{M})$. In contrast to $\mathbf{1}-\mathbf{3}$, starting copper salt and free ligands in similar conditions had relatively less activity towards normal and cancer lines. Cisplatin displayed with regard to normal human cells weaker activity against cancer cell lines A549 and MCF7 and comparable against HeLa cell line. Similarly, complex 2 seemed to be more toxic in the case of NHDF cell line in comparison to all cancer lines.

It may be interesting to compare the activity of compounds 1-3 with the copper(I)-dmphenphosphine complexes described in literature, especially as the influence of copper(I) compounds on cancer cells is well known. They usually show strong or moderate anticancer effect. However, they are not always safe for normal cells. According to Komarnicka et al. reported data, $\mathrm{IC}_{50}$ value for $[\mathrm{Cu}$ (iodide)(dmphen $\left.)\left(\mathrm{P}\left(p-\mathrm{OCH}_{3}-\mathrm{Ph}\right)_{2} \mathrm{CH}_{2} \mathrm{OH}\right)\right]$ showed $62.01 \mu \mathrm{M}$ for A549 cell line, while, at the same time, already 32-43 $\mu \mathrm{M}$ was toxic for normal cell lines like MRC5, HEK293T, or HaCat [38]. In our case, not only that complexes 1 and 3 were less toxic for NHDF (normal cells) than A549, but also smaller than in the case of $[\mathrm{Cu}$ (iodide $\left.)(\mathrm{dmphen})\left(\mathrm{P}\left(p-\mathrm{OCH}_{3}-\mathrm{Ph}\right)_{2} \mathrm{CH}_{2} \mathrm{OH}\right)\right]$ doses $(0.29$ and $0.43 \mu \mathrm{M}$, respectively) were cytotoxic for cancer cells. A similar situation was observed in regard to [Cu(iodide)(dmphen)( $\left.\left.\mathrm{P}\left(p-\mathrm{OCH}_{3}-\mathrm{Ph}\right)_{2} \mathrm{CH}_{2}-\mathrm{SarGly}\right)\right]$, where $\mathrm{IC}_{50}$ value for $\mathrm{A} 549$ was $>100 \mu \mathrm{M}$. On the other hand, in the case of MCF7 cell line, both mentioned-above copper-iodide complexes showed better anticancer properties than $\mathbf{1}$ and 3, which confirmed that the same compounds may be toxic for one type of neoplasia and nontoxic for others [38].

$\mathrm{Cu}$ (II) compounds acted differently on cells. Some of them, e.g., Schiff base copper(II) complexes type $\left.\left[\mathrm{Cu}_{2} \text { (sal-D,L-glu) }{ }_{2} \text { (isoquinoline) }\right)_{2}\right] \cdot 2 \mathrm{EtOH},\left[\mathrm{Cu}\left(\right.\right.$ sal-5-met-L-glu) $\left.\left(\mathrm{H}_{2} \mathrm{O}\right)\right] \cdot \mathrm{H}_{2} \mathrm{O}$, 
$\left[\mathrm{Cu}(\mathrm{EtOH})_{2}(\text { imidazole })_{4}\right]$, and $\left[\mathrm{Cu}_{2}(\text { sal-D,L-glu })_{2}(\text { imidazole })_{2}\right]$, showed weak $\left(\mathrm{IC}_{50}\right.$ value $\left.>100 \mu \mathrm{M}\right)$ cytotoxic effect on A549 or HeLa lines [76]. Others, guanidine copper(II) complexes type $\left(\mathrm{Cu}\left(\mathrm{C}_{4} \mathrm{H}_{3} \mathrm{SCONC}(\mathrm{NHR}) \mathrm{NPh}\right)_{2}\right)(\mathrm{R}=$ aliphatic or aromatic groups), were cytotoxic for MCF7 and A549, but in much higher doses (61.1-370 $\mu \mathrm{M})$ than 1-3 [77]. Toxicity of the aforementioned compounds for normal cells was also unknown [77]. Ganeshpandian et al. [78] reported $\mathrm{Cu}$ (II) compounds bearing dmphen ligand type $[\mathrm{Cu}(\mathrm{L})(\mathrm{dmphen})]\left[\mathrm{ClO}_{4}\right]_{2}(\mathrm{~L}=$ substituted derivatives of amines), for which influence on MCF7 was tested. Series of these complexes were cytotoxic for human breast cells, but these doses, although lower than cisplatin, were several times higher (between $16.7 \mu \mathrm{M}$ and $22.1 \mu \mathrm{M}$ ) compared to 1, 2, and 3. In light of these studies, compounds 1, 3, and even $\mathbf{2}$ seem promising as potential anticancer agents, especially because, in contrast to cited-above reports, complexes, 1-3 were tested only in aqua media.

The bioactivities of the compounds is often compared with values of their logarithm of 1-octanol/water partition coefficient $(\log (\mathrm{P})$, see Experimental). This method describes hydrophobic/hydrophilic properties of the compounds. For the accurate biological activity and bioavailability of potential drugs, a balanced solubility in both water and nonpolar compounds such as lipids is essential [79]. Indeed, the different activities of the copper complexes 1-3 could be related to their positive, low $\log (\mathrm{P})$ values $(0.90-1.75)$, in contrast to cisplatin with strongly negative $\log (\mathrm{P})$ factor $(-2.21)$ [80].

\subsection{Apo-Transferrin Interactions}

Figure 5 shows the fluorescence emission spectra of apo-Tf - copper complexes systems registered under physiological conditions and the excitation wavelength at $280 \mathrm{~nm}$. It was evident that apo-Tf showed a strong fluorescence band at $325.5 \mathrm{~nm}$ and titration of the protein with small amounts of the complexes causing distinct decrease in fluorescence intensity of the protein. Moreover, the maximum band position was red shifted to ca. $330.5 \mathrm{~nm}$. All the observations indicate that the apo-Tf conformation was changed and the protein's chromophores were moved to a more polar environment [81].

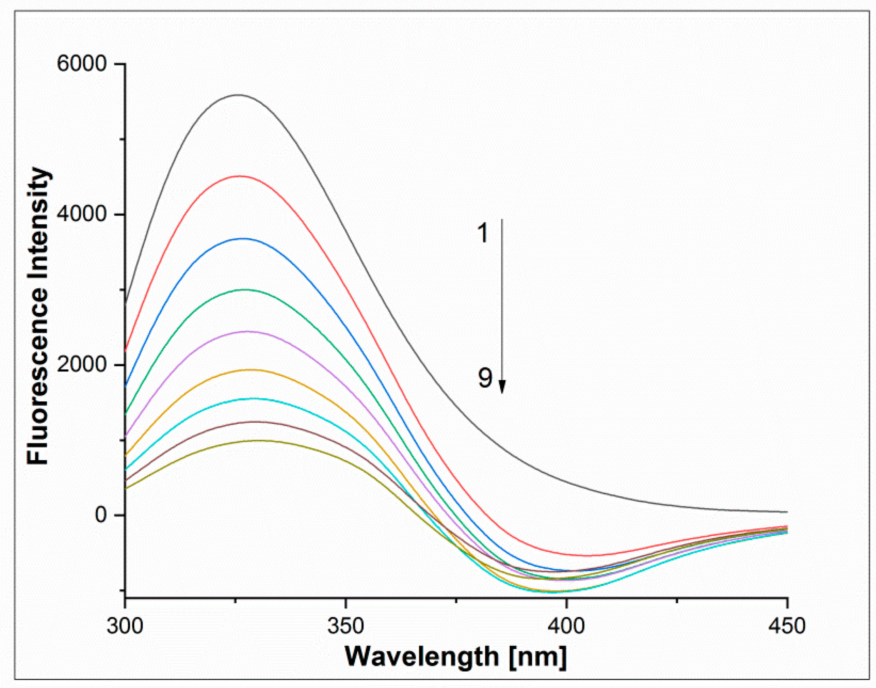

Figure 5. Fluorescence emission spectra of apo-Tf - 3 systems under physiological conditions (Phosphate-Buffered Saline-PBS, $\mathrm{pH}=7.40, \mathrm{~T}=310 \mathrm{~K}$ ), $\lambda_{\mathrm{ex}}=280 \mathrm{~nm}, \mathrm{C}_{\text {apo-Tf }}=2 \cdot 10^{-6} \mathrm{M}$.

There are two mechanisms of fluorescence quenching, dynamic and static, that can be distinguished based on the temperature dependency. Dynamic quenching is due to collisions between quencher and fluorophore and static quenching results from the formation of the ground state complex between the molecules [82]. A modified Stern-Volmer equation (Equation (3)) was used to calculate Stern-Volmer 
quenching constants $\left(\mathrm{K}_{\mathrm{SV}}\right)$ and quenching rate constants $(\mathrm{Kq})$ of the interactions between apo-transferrin and copper complexes and to determine the mechanism of fluorescence quenching.

$$
\mathrm{Fo} /(\mathrm{Fo}-\mathrm{F})=1 / \mathrm{fa}+1 /(\mathrm{faKsv}[\mathrm{Q}])
$$

In the equation, Fo and $\mathrm{F}$ are the fluorescence intensities of protein in the absence and presence of the quencher in the concentration $(\mathrm{Q})$, respectively; $\mathrm{K}_{\mathrm{SV}}$ is the Stern-Volmer quenching constant; and $\mathrm{fa}$ is the fraction of the fluorophore accessible to the quencher.

$\mathrm{Kq}$, the quenching rate constant of the biomolecules, is expressed as:

$$
\mathrm{Kq}=\mathrm{Ksv} / \tau \mathrm{o}
$$

where $\tau$ o is the fluorescence lifetime of protein without quencher. For apo-transferrin, the to value is $2.5 \mathrm{~ns}$ [83].

The modified Stern-Volmer plots are shown in Figure 6A, and Table 3 lists quenching parameters. As shown, the Ksv values increased with the temperature increases in the case of apo-Tf - complex 1 and complex 2 systems $\left(2.50-5.69 \cdot 10^{4} \mathrm{M}^{-1}\right)$. Simultaneously, the proper Kq values $\left(10^{13}-10^{14}\right.$ $\left(\mathrm{M}^{-1} \mathrm{~s}^{-1}\right)$ ) were higher than $2 \times 10^{10} \mathrm{M}^{-1} \mathrm{~s}^{-1}$, the maximum $\mathrm{Kq}$ value expected for dynamic processes of the biopolymers $[84,85]$. Therefore, we concluded that some specific interactions were involved in the reaction between apo-Tf- copper complexes $\mathbf{1 / 2}$ that mad Kq greater, and the fluorescence quenching was initiated by both static and dynamic processes. In the case of apo-Tf - complex 3 system, the Ksv values $\left(5.37 \times 10^{4}\right.$ and $3.51 \times 10^{4}$ in $300 \mathrm{~K}$ and $310 \mathrm{~K}$, respectively) were reversely correlated with the temperature, indicating static fluorescence quenching mechanism.

Table 3. The quenching parameters of the apo-Tf - Cu systems.

\begin{tabular}{cccc}
\hline Parameter & Complex & 300K & 310K \\
\hline $\mathbf{K s v} \cdot \mathbf{1 0}^{\mathbf{4}}\left[\mathbf{M}^{\mathbf{- 1}}\right]$ & $\mathbf{1}$ & $2.50 \pm 0.011$ & $2.92 \pm 0.029$ \\
& $\mathbf{2}$ & $4.03 \pm 0.050$ & $5.69 \pm 0.024$ \\
& $\mathbf{3}$ & $5.37 \pm 0.023$ & $3.51 \pm 0.062$ \\
$\mathbf{K q} \cdot \mathbf{1 0}^{\mathbf{1 3}}\left[\mathbf{M}^{\mathbf{- 1}} \mathbf{s}^{\mathbf{- 1}}\right]$ & $\mathbf{1}$ & $1.00 \pm 0.011$ & $1.17 \pm 0.029$ \\
& $\mathbf{2}$ & $1.61 \pm 0.050$ & $2.27 \pm 0.024$ \\
& $\mathbf{3}$ & $0.12 \pm 0.023$ & $1.40 \pm 0.062$ \\
\hline
\end{tabular}

Association constants (Ka) and number of binding sites (n) were determined based on the Equation (5):

$$
\log \{(\mathrm{Fo}-\mathrm{F}) / \mathrm{F}\}=\log \mathrm{Ka}+\mathrm{nlog}[\mathrm{Q}]
$$

where Fo and $\mathrm{F}$ are the fluorescence intensities in the absence and presence of the quencher in the concentration $(\mathrm{Q})$, respectively, $\mathrm{Ka}$ is the binding constant, and $\mathrm{n}$ is the number of binding sites.

All binding data are collected in Table 4 and appropriate plots are shown in Figure 6B. It is clear that under tested conditions only one binding site (n) in protein for all copper complexes existed. The association constants (Ka) decreased with the temperature increases for $\mathbf{1}$ and $\mathbf{2}$, suggesting forming of the unstable complexes. The binding constant of apo-Tf -3 system increased with temperature increase, indicating the formation of the stable adduct and endothermic process.

The interactions of the tested compounds with apo-Tf were definitely stronger than that of cisplatin $\left(10^{6}-10^{7} \mathrm{M}^{-1}\right.$ vs. $0.20-0.35 \mathrm{M}^{-1}$, respectively) [86,87]. Moreover, obtained association constants were higher than association constant of chromium(III)-phen - apo-Tf system $\left(1.5 \times 10^{5} \mathrm{M}^{-1}\right)$ [88] or those obtained for NAMI-A (- Imidazolium-trans-tetrachloro(dimethylsulfoxide)imidazoleruthenium(III) name explained in [89]) and its reduced form $\left(1.28 \times 10^{4} \mathrm{M}^{-1}\right.$ and $1.36 \times 10^{4} \mathrm{M}^{-1}$, respectively) [89]. 
Table 4. The binding parameters of the apo-Tf-Cu systems.

\begin{tabular}{cccc}
\hline Parameter & Complex & 300K & 310K \\
\hline \multirow{3}{*}{$\mathbf{K a} \cdot \mathbf{1 0}^{\mathbf{6}}\left[\mathbf{M}^{-\mathbf{1}}\right]$} & $\mathbf{1}$ & $1.03 \pm 0.16$ & $0.843 \pm 0.17$ \\
& $\mathbf{2}$ & $4.38 \pm 0.24$ & $3.04 \pm 0.32$ \\
& $\mathbf{3}$ & $9.26 \pm 0.37$ & $9.38 \pm 0.33$ \\
$\mathbf{n}$ & $\mathbf{1}$ & $1.26 \pm 0.033$ & $1.24 \pm 0.036$ \\
& $\mathbf{2}$ & $1.35 \pm 0.050$ & $1.31 \pm 0.066$ \\
& $\mathbf{3}$ & $1.40 \pm 0.076$ & $1.42 \pm 0.068$ \\
\hline
\end{tabular}
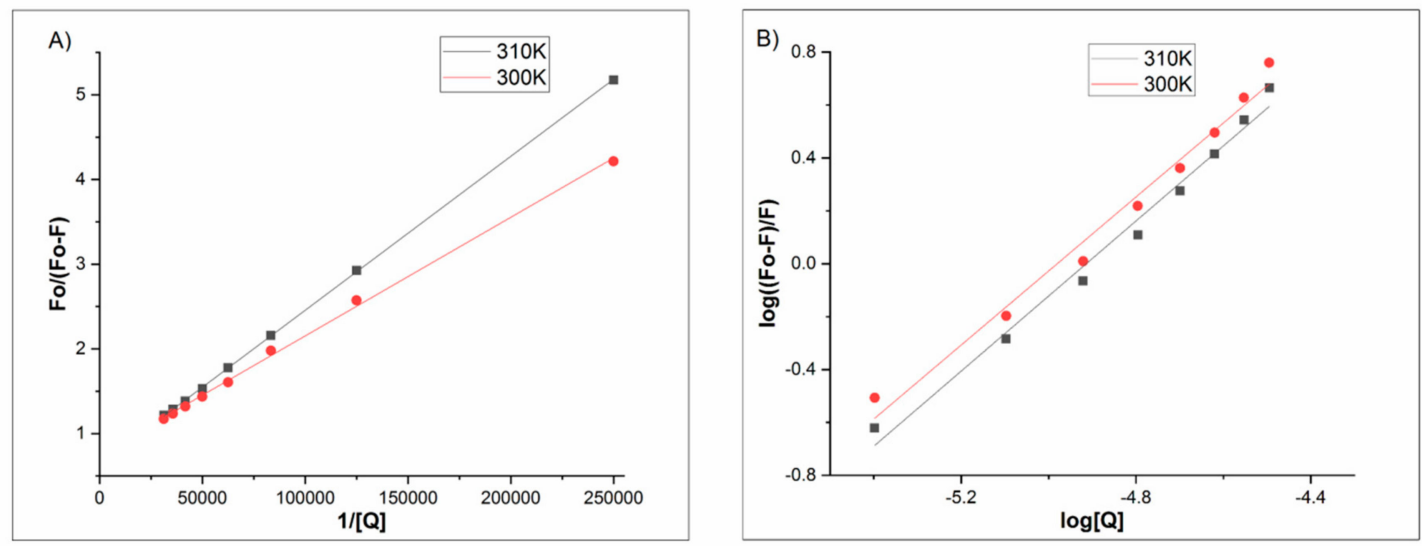

Figure 6. Modified Stern-Volmer $(\mathbf{A})$ and $\log \left(\left(\mathrm{F}_{0}-\mathrm{F}\right) / \mathrm{F}\right)$ vs. $\log (\mathrm{Q})(\mathbf{B})$ plots of the apo-Tf- 3 system at $300 \mathrm{~K}$ and $310 \mathrm{~K}$ (PBS, $\mathrm{pH}=7.40, \lambda \mathrm{ex}=280 \mathrm{~nm})$.

It is known that interactions between proteins and small molecules include hydrogen bonds, van der Waals, and electrostatic forces as well hydrophobic interactions [90]. Based on thermodynamic parameters, we determined the type of interaction of copper complexes with apo-transferrin. Table 5 shows all $\Delta \mathrm{H}^{0}, \Delta \mathrm{S}^{0}$, and $\Delta \mathrm{G}^{0}$ values obtained from van't Hoff plots and Equations (6) and (7):

$$
\begin{aligned}
\ln K a & =-\frac{\Delta H^{0}}{R T}+\frac{\Delta S^{0}}{R} \\
\Delta \mathrm{G}^{0} & =\Delta \mathrm{H}^{0}-\mathrm{T} \Delta S^{0}
\end{aligned}
$$

where $\mathrm{Ka}$ is the bimolecular binding constant at the corresponding temperature $(\mathrm{T})$; $\mathrm{R}$ is the gas constant; and $\Delta \mathrm{H}^{0}, \Delta \mathrm{S}^{0}$, and $\Delta \mathrm{G}^{0}$ are enthalpy, entropy, and free energy change, respectively.

\begin{tabular}{|c|c|c|c|c|c|c|c|c|c|}
\hline \multirow[t]{2}{*}{$\mathrm{T}[\mathrm{K}]$} & \multicolumn{3}{|c|}{$\mathrm{H}^{0}\left[\mathrm{~kJ} \mathrm{~mol}^{-1}\right]$} & \multicolumn{3}{|c|}{$\mathrm{S}^{0}\left[\mathrm{~J} \mathrm{~mol}^{-1} \mathrm{~K}^{-1}\right]$} & \multicolumn{3}{|c|}{$\mathrm{G}^{0}\left[\mathrm{~kJ} \mathrm{\textrm {mol } ^ { - 1 } ]}\right.$} \\
\hline & 1 & 2 & 3 & 1 & 2 & 3 & 1 & 2 & 3 \\
\hline $\begin{array}{l}300 \\
310\end{array}$ & -15.33 & -28.24 & 962.34 & 63.99 & 33.02 & 136.57 & $\begin{array}{l}-34.53 \\
-35.17\end{array}$ & $\begin{array}{l}-38.15 \\
-38.45\end{array}$ & $\begin{array}{l}-40.01 \\
-41.37\end{array}$ \\
\hline
\end{tabular}

Table 5. Thermodynamic parameters of the apo-Tf - Cu systems at 300 and $310 \mathrm{~K}$.

The positive $\Delta \mathrm{S}^{0}$ and negative $\Delta \mathrm{H}^{0}$ for complexes $\mathbf{1}$ and $\mathbf{2}$ suggest that electrostatic interactions were involved in the reaction between protein and complexes. Both positive $\Delta \mathrm{H}^{0}$ and $\Delta \mathrm{S}^{0}$ for $\mathbf{3}$ indicate hydrophobic and ionic interactions. Negative values for all systems point to spontaneous processes.

Circular dichroism (CD) measurements in the far UV region were performed to determine the effect of copper complexes on the apo-transferrin secondary structure. A characteristic for $\alpha$-helical structure of protein negative bands was visible in the CD spectrum at wavelengths of 210 and 220 nm (Figure 7) and were assigned $n-\pi^{*}$ transitions peptide bonds. All the tested complexes did not generate $\mathrm{CD}$ signal in the measured range. The $\alpha$-helix content the free protein was equal to $19.80 \%$. 
The interaction of $\mathbf{1}$ and $\mathbf{2}$ with apo-Tf had an insignificant effect on its secondary structure and, upon binding, the complexes $\alpha$-helix content decreased to $19.07 \%$ and $18.00 \%$, respectively, when the molar ratio apo-Tf:1/2 was 1:20. In contrast to $\mathbf{1}$ and $\mathbf{2}$, binding $\mathbf{3}$ complex to apo-transferrin caused extensive changes in conformation of the protein reducing $\alpha$-helix content to $17.05 \%$ and $8.16 \%$ at the molar ratios apo-Tf:3 equal 1:10 and 1:20, respectively.

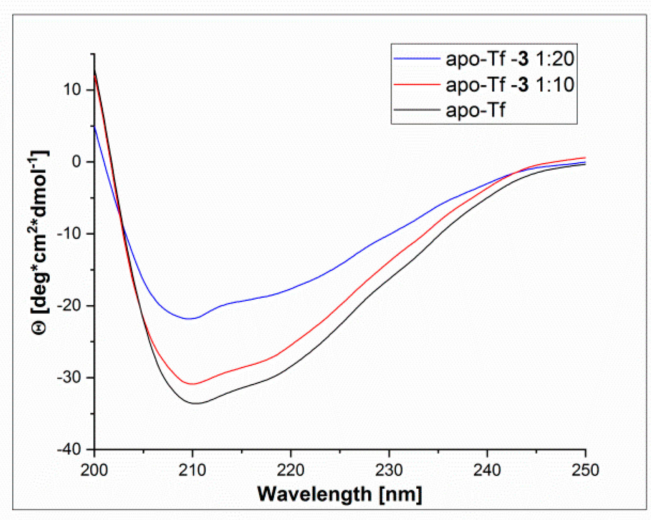

Figure 7. Circular dichroism -CD spectra of apo-Tf -3 systems under physiological conditions (PBS, $\mathrm{pH}=7.40, \mathrm{~T}=310 \mathrm{~K})\left(\mathrm{C}_{\mathrm{apo}-\mathrm{Tf}}=5 \times 10^{-6} \mathrm{M}\right)$.

\section{Experimental}

\subsection{Materials and Methods}

All syntheses of compounds were carried out at room temperature (r.t.) in air. PTA=O (1,3,5-Triaza-7-phosphaadamantane-7-oxide) was synthesized following a reported procedure [91,92]. All other chemicals $\mathrm{Cu}\left(\mathrm{NO}_{3}\right)_{2} \cdot 3 \mathrm{H}_{2} \mathrm{O}$ (POCH, Gliwice, Poland), $\mathrm{CuCl}_{2} \cdot 2 \mathrm{H}_{2} \mathrm{O}(\mathrm{CHEMPUR}$, Piekary Ślaskie, Poland), $\mathrm{KPF}_{6}$, dmphen (Sigma-Aldrich, St. Louis, USA), and analytical grade solvents, MeCN (Sigma-Aldrich, St. Louis, USA,), EtOH, and 1-octanol (POCH, Gliwice, Poland), were used without further purification. Elemental analyses were performed on the Elemental Analyser VarioELCube (Elementar Analysensysteme GmbH, Hanau, Germany) by the Laboratory of Elemental Analysis at Faculty of Chemistry, University of Wrocław. Infrared (IR) spectra were measured on a Bruker 70 Vertex 70 FTIR (Bruker, Ettlingen, Germany) instrument in the $4000-400 \mathrm{~cm}^{-1}$ range by the Laboratory of Infrared Spectroscopy at Faculty of Chemistry, University of Wrocław (abbreviations: vs, very strong; s, strong; m, medium; w, weak; vw, very weak; br., broad).

\subsection{Cell Cultures}

Normal human dermal fibroblasts (NHDF) (PromoCell, C-12302) were used as normal cells and LoVo (human colorectal adenocarcinoma, ATCC ${ }^{\circledR}$ CCL-229 ${ }^{\mathrm{TM}}$ ), A549 (human lung carcinoma, ATCC, No. CCL-185 TM), MCF-7 (human breast adenocarcinoma, ATCC, No. HTB-22 ${ }^{\text {TM}}$ ) and HeLa (human cervix carcinoma, ATCC, No. CCL-2 TM) were used as cancer cells. They were cultured in DMEM, DMEM-F12 or EMEM (Lonza, CA, USA). Media were supplemented with 10\% FBS (Biological Industries, Kibbutz Beit-Haemek, Israel), 2 mM L-glutamine (Biological Industries, Israel), 100 U/mL of penicillin and $100 \mu \mathrm{g} / \mathrm{mL}$ of streptomycin (Sigma, Neustadt an der Weinstrasse, Germany).

\subsection{Cytotoxic Properties on Normal and Cancer Cell Lines - Quantitative Suspension Test According to EN 14476}

The $100 \mu \mathrm{L}$ of suspension of NHDF, A549, HeLa, LoVo, and MCF7 cells at a density of $4 \times 10^{4}$ cells $\mathrm{mL}^{-1}$ were incubated in a 96-well polystyrene plate (NUNC, Denmark) for $24 \mathrm{~h}$ [93]. Product test solutions were prepared in DMEM, DMEM-F12, or EMEM supplemented with additional 2\% FBS and $2 \mathrm{mM}$ L-glutamine. Solutions of the reagents at concentrations from 460 (for 1), 454 (2), 690 (3), 1242 
$\left(\mathrm{Cu}\left(\mathrm{NO}_{3}\right)_{2}\right), 1732(\mathrm{PTA}=\mathrm{O})$, and $1440 \mu \mathrm{M}$ (dmphen) to $4.60 \times 10^{-6}, 4.54 \times 10^{-6}, 4.69 \times 10^{-6}, 1.24 \times 10^{-5}$, $1.73 \times 10^{-5}$, and $1.44 \times 10^{-5} \mu \mathrm{M}$, respectively, were prepared and transferred $(100 \mu \mathrm{L})$ into cell culture units (wells of microtiter plates) containing monolayer of cells. Eight units were inoculated with each dilution. Plates were incubated in $37^{\circ} \mathrm{C}, 5 \% \mathrm{CO}_{2}$ and observed daily for 4 days for the development of cytotoxic effect, using an inverted microscope (Olympus Corp., Hamburg, Germany, Axio Observer, Carl Zeiss MicroImaging $\mathrm{GmbH}$ ). Then the wells were washed in phosphate buffered saline (PBS) and stained using DAPI (4', 6 -diamidino-2-phenylindole) and propidium iodide (Merck, Darmstadt, Germany). The study used the fact that DAPI is able to be combined with cellular DNA, permeate through the membrane of cell, rapidly enter the nucleus of living cells and bind with DNA to form a DAPI-DNA complex. Propidium iodide does not pass through the membranes in healthy cells, but as a result of its damage it can penetrate into the cell. In cell culture these are cells that are apoptotic or damaged by any physical or chemical agent. Therefore, if these two fluorochrome are given at the same time, DAPI will get to healthy cells faster, while propidium iodide will stain dead or dying cells. The calculation of the ratio of cells counted on a specific area, allows to determine the potency of a substance in inhibiting a specific biological function $\left(\mathrm{IC}_{50}\right)$.

\subsection{Apo-Transferrin Interactions}

High purity apo-transferrin ( $\geq 98 \%$, Sigma-Aldrich, Steinheim, North Rhine-Westphalia, Germany) was used without prior purification. The stock solutions of the complexes were prepared in demineralized water (1 and $\mathbf{2}$ ) or ethanol (3). The apo-Tf was dissolved in PBS (pH 7.40). The molar ratios of the final samples in PBS were (protein):(drug) = 1:0-1:16 in PBS with the protein concentration equal $2 \mu \mathrm{M}$. Samples were incubated at 300 and $310 \mathrm{~K}$ for $5 \mathrm{~min}$. The apo-Tf concentration was determined using $\mathcal{\varepsilon}(280 \mathrm{~nm})=11.2 \mathrm{mM}^{-1} \times \mathrm{cm}^{-1}$.

\subsubsection{Fluorescence Spectroscopy}

Emission fluorescence spectra were recorded on Jasco 8200 spectrofluorimeter (Tokyo, Japan) in the range of 300-500 nm using $1.0 \mathrm{~cm}$ quartz cells. The $\lambda$ ex was set to $280 \mathrm{~nm}$ and the excitation and emission slit widths were set to $5 \mathrm{~nm}$. All fluorescence intensities were corrected (according to Equation (8)) for the inner filter and dilution effects and the corrected values were used to determine the quenching mechanism and binding data. Moreover, the copper complexes showed a fluorescence signal in the measured range. Therefore, all spectra are shown as different spectra of (apo-Tf-copper complex)-(copper complex).

$$
\mathrm{F}_{\text {corr }}=\exp \left(\mathrm{A}_{280}+\mathrm{A}_{\mathrm{em}} / 2\right) \times \mathrm{F}_{\mathrm{exp}}
$$

\subsubsection{Spectroscopy}

Circular dichroism measurements were carried out on a Jasco J-715 spectropolarimeter (Tokyo, Japan) in the range of $190-250 \mathrm{~nm}$ using $0.1-\mathrm{cm}$ cuvettes. The $\alpha$-helical content of the protein was calculated from the Equations (9) and (10):

$$
\begin{gathered}
\text { MRE }_{209}=\frac{\text { Observed }_{C D}(\text { mdeg })}{C_{p} \cdot n \cdot l \cdot 10} \\
\alpha-\text { helix }(\%)=-\frac{M R E_{209}-4000}{33000-4000} \times 100
\end{gathered}
$$

where MRE is the mean residue ellipticity, $C_{p}$ is the molar concentration of the protein, $n$ the number of amino acid residues (679), and $l$ is the path length $(0.1 \mathrm{~cm})$.

\subsection{Synthesis and Analytical Data}

The $\left[\mathrm{Cu}\left(\mathrm{NO}_{3}\right)(\mathrm{PTA}=\mathrm{O})(\mathrm{dmphen})\right]\left[\mathrm{PF}_{6}\right](\mathbf{1}): 241.6 \mathrm{mg}$ of $\mathrm{Cu}\left(\mathrm{NO}_{3}\right) \cdot 3 \mathrm{H}_{2} \mathrm{O}(1.0 \mathrm{mmol})$ was dissolved in $40 \mathrm{~mL}$ of ethanol at room temperature and treated with $173.15 \mathrm{mg}(1 \mathrm{mmol})$ solid PTA=O. During 
stirring for $1 \mathrm{~h}$, the color of the solution changed from blue to green. Solid dmphen ( $208.25 \mathrm{mg}, 1 \mathrm{mmol})$ with $\mathrm{KPF}_{6}(184.1 \mathrm{mg}, 1 \mathrm{mmol})$ were added and the obtained mixture was refluxed for $2 \mathrm{~h}$ and then filtered off. The filtrate was left to slowly evaporate at $\sim 4{ }^{\circ} \mathrm{C}$ for several days, producing green $\mathrm{X}$-ray quality single crystals of $\mathbf{1}$ and red byproduct, determined as $\left(\mathrm{Cu}(\mathrm{dmphen})_{2}\right)\left(\mathrm{PF}_{6}\right)_{2}$. The main product was washed with dimethylformamide/acetone and dried in air to furnish 1 in $36 \%$ yield (234 mg), based on the copper(II) salt. The 1 was soluble in $\mathrm{H}_{2} \mathrm{O}\left(\mathrm{S}_{25}{ }^{\circ} \mathrm{C} \approx 3.8 \mathrm{mg} \mathrm{mL}^{-1}\right)$, DMSO, and $\mathrm{MeOH}$; sparingly soluble in $\mathrm{CH}_{2} \mathrm{Cl}_{2}$ and $\mathrm{EtOH}$; and insoluble in toluene and alkanes. Anal. Calcd. for $\mathrm{C}_{20} \mathrm{H}_{24} \mathrm{CuN}_{6} \mathrm{O}_{4} \mathrm{P}_{2} \mathrm{~F}_{6}$ (MW 651.9): $\mathrm{C}, 36.85 ; \mathrm{H}, 3.71 ; \mathrm{N}, 12.89$; found: $\mathrm{C}, 37,18 ; \mathrm{H}, 3.62 ; \mathrm{N}, 12.91$. IR (KBr, cm $\left.{ }^{-1}\right)$ : 3435 (s, br), $3065(\mathrm{~m}), 2980(\mathrm{~m}), 2923(\mathrm{w}), 2880(\mathrm{~m}), 2546(\mathrm{~m}), 2256(\mathrm{~m}), 1996(\mathrm{~m}), 1939$ (m), 1837 (m), $1768(\mathrm{~m}), 1710(\mathrm{~m}), 1628(\mathrm{~m}), 1618$ (w), 1597 (s), 1572 (s), 1535 (vs), 1513 (vs), 1504 (vs), 1445 (s), 1430 (s), 1414 (s), 1384 (vs), 1365 (vs), 1303 (s), 1292 (vs), 1279 (vs), 1261 (vs), 1248 (vs), 1233 (vs), 1207 (m), 1158 (s), 1130 (vs), 1094 (s), 1044 (w), 1018 (s), 1006 (vs), 992 (m), 973 (vs), 943 (s), 910 (s), 869 (vs), 838 (vs), 814 (vs), 801 (vs), 792 (vs), 763 (s), 738 (m), 727 (s), 683 (m), 664 (w), 578 (s), 558 (vs), $470(\mathrm{~m}), 450(\mathrm{~m}), 442(\mathrm{w}), 432(\mathrm{w}), 421(\mathrm{w}), 388(\mathrm{~m})$.

The $\left[\mathrm{Cu}(\mathrm{Cl})(\mathrm{dmphen})_{2}\right]\left[\mathrm{PF}_{6}\right](2)$ : The following one-pot reaction was faster and yielded a cleaner product than the previously published method [49]. The $170.5 \mathrm{mg}$ of $\mathrm{CuCl}_{2} \cdot 2 \mathrm{H}_{2} \mathrm{O}(1.0 \mathrm{mmol})$ was dissolved in $40 \mathrm{~mL}$ of ethanol at room temperature and treated with $217.5 \mathrm{mg}(1 \mathrm{mmol}) \mathrm{dmphen}$ and $\mathrm{KPF}_{6}(184.1 \mathrm{mg}, 1 \mathrm{mmol})$. The obtained mixture was refluxed for $2 \mathrm{~h}$ and then filtered off. During the process the color of the cloudy solution changed from blue to yellow-green. The filtrate was left to slowly evaporate at $\sim 4{ }^{\circ} \mathrm{C}$ for several days, producing green X-ray quality single crystals of 2 in $40 \%$ yield $(265.7 \mathrm{mg})$, based on the copper(II) salt. The 2 was soluble in $\mathrm{H}_{2} \mathrm{O}\left(\mathrm{S}_{25}{ }^{\circ} \mathrm{C} \approx 2.5 \mathrm{mg} \mathrm{mL}^{-1}\right)$, DMSO, and $\mathrm{MeOH}$ and $\mathrm{EtOH}$; sparingly soluble in $\mathrm{CH}_{2} \mathrm{Cl}_{2}$; and insoluble in toluene and alkanes. Anal. Calcd. for $\mathrm{C}_{28} \mathrm{H}_{24} \mathrm{ClCuN}_{4} \mathrm{PF}_{6}$ (MW 660.5): $\mathrm{C}, 50.92 ; \mathrm{H}, 8.48 ; \mathrm{N}, 8.48$; found: $\mathrm{C}, 50.90 ; \mathrm{H}, 3.63 ; \mathrm{N}$, 8.44. IR ( $\mathrm{KBr}$, $\mathrm{cm}^{-1}$ ): $3272(\mathrm{~s}), 3057(\mathrm{w}), 2923(\mathrm{w}), 1613(\mathrm{~m}), 1593(\mathrm{~s}), 1565(\mathrm{~m}), 1505(\mathrm{~s}), 1447(\mathrm{~m}), 1426(\mathrm{~m}), 1418(\mathrm{~m})$, $1364(\mathrm{~s}), 1294(\mathrm{w}), 1251(\mathrm{w}), 1224(\mathrm{w}), 1215(\mathrm{w}), 1159(\mathrm{w}), 1147(\mathrm{~s}), 1105(\mathrm{w}), 1035(\mathrm{w}), 996(\mathrm{w}), 987(\mathrm{w})$, $940(\mathrm{vw}), 863(\mathrm{vs}), 841(\mathrm{w}), 813(\mathrm{w}), 801(\mathrm{~m}), 776(\mathrm{~m}), 732(\mathrm{~s}), 697(\mathrm{~m}), 682(\mathrm{w}), 656(\mathrm{~m}), 581(\mathrm{w}), 550(\mathrm{~s})$, $434(\mathrm{w})$.

The $\left[\mathrm{Cu}\left(\mathrm{NO}_{3}\right)_{2}(\mathrm{dmphen})\right] \cdot \mathrm{MeCN}$ (3): $241.6 \mathrm{mg}$ of $\mathrm{Cu}\left(\mathrm{NO}_{3}\right) \cdot 3 \mathrm{H}_{2} \mathrm{O}(1.0 \mathrm{mmol})$ was dissolved in $50 \mathrm{~mL}$ of acetonitrile at room temperature and treated with $217.5 \mathrm{mg}(1 \mathrm{mmol}) \mathrm{dmphen}$. The obtained mixture was refluxed for $2 \mathrm{~h}$ and then filtered off. During the process the color of the solution changed from blue to green-brown. The filtrate was left to slowly evaporate at $\sim 4{ }^{\circ} \mathrm{C}$ for one day, producing green X-ray quality single crystals of 3 in $85 \%$ yield ( $371 \mathrm{mg}$ ), based on the copper(II) salt. The 3 was soluble in $\mathrm{H}_{2} \mathrm{O}\left(\mathrm{S}_{25}{ }^{\circ} \mathrm{C} \approx 2.9 \mathrm{mg} \mathrm{mL}^{-1}\right)$, DMSO, and acetone and $\mathrm{MeOH}$; sparingly soluble in $\mathrm{CH}_{2} \mathrm{Cl}_{2}$; and insoluble in toluene and alkanes. Anal. Calcd. for $\mathrm{C}_{16} \mathrm{H}_{15} \mathrm{CuN}_{5} \mathrm{O}_{6}$ (MW 436.9): C, 43.99; H, 3.46; N, 16.03; found: C, 43.95; H, 3.43; N, 16.00. IR (KBr, cm $\left.{ }^{-1}\right): 3420$ (s, br), 3073 (w), 2492 (m), 2285 (m), $2247(\mathrm{~m}), 1991(\mathrm{~m}), 1844(\mathrm{~m})$, 1767(m), $1719(\mathrm{~m}), 1625(\mathrm{~m}), 1594(\mathrm{~s}), 1570(\mathrm{~s}), 1500$ (vs), 1365 (vs), 1273 (vs), 1248 (vs), 1217 (s), 1205 (s), 1156 (s), 1110 (m), 1034 (s), 1017 (vs) 1003 (vs), 979 (m), 943 (m), $865(\mathrm{vs}), 805(\mathrm{~s}), 789(\mathrm{~m}), 747(\mathrm{~m}), 729(\mathrm{~s}), 707(\mathrm{w}), 683(\mathrm{~m}), 663(\mathrm{~m}), 632(\mathrm{w}), 552(\mathrm{~m}), 527(\mathrm{~m}), 456(\mathrm{~m})$, $442(\mathrm{w}), 419(\mathrm{w}), 376(\mathrm{vw})$.

\subsection{Stability/Solubility Tests and Octanol-Water Partition Coefficient Determination}

The copper complexes 1-3 were air stable in the solid state and at least for several days in $\mathrm{H}_{2} \mathrm{O}$ solutions. In a general procedure, the complex was dissolved in $\mathrm{H}_{2} \mathrm{O}$ in air atmosphere. IR spectra of the solid samples after evaporation of the solvent under vacuum showed that no evident changes were produced in several days at room temperature. Also UV-Vis spectra of water solutions of 1-3 confirm their stability in several days. In a stepwise procedure of the solubility determination, increasing volumes of water were added at $25^{\circ} \mathrm{C}$ to approximately $5 \mathrm{mg}$ of the compound in a $5 \mathrm{~mL}$ glass tube. After each addition of an amount of water $(100 \mu \mathrm{L})$, the mixture was shaken for several minutes and then visually checked for any undissolved parts of the sample. 
The $\log \mathrm{P}$ values consistent to the octanol-water partition coefficient were adjusted to the solubility properties of the compounds [94]. Complexes 1-3 were dissolved in water, previously saturated with octanol with concentrations $10^{-5} \mathrm{M}$. Into a $25-\mathrm{mL}$ flask at room temperature with a magnetic stir bar was introduced initially $5 \mathrm{~mL}$ of octanol previously saturated with water and then $5 \mathrm{~mL}$ of the complex solutions in water. A two-phase mixture was stirred vigorously for $15 \mathrm{~min}$ and samples, which were measured by UV-Vis spectroscopy, were taken from the separated phases. Values of $\log \mathrm{P}$ have been found as $0.90,1.75$, and 1.11 , for $\mathbf{1}, \mathbf{2}$, and $\mathbf{3}$, respectively.

\subsection{X-ray Crystallography}

Single crystal data collection was performed on KUMA diffractometer with Sapphire CCD detector, equipped with an Oxford Cryosystems open-flow nitrogen cryostat, using $\omega$-scan and a

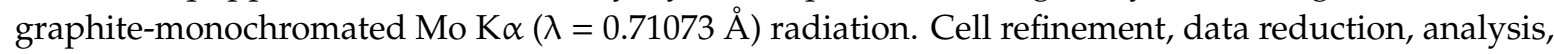
and absorption correction were carried out with CRYSALISPro (Rigaku Oxford Diffraction, Wrocław, Poland) software. The structures were solved by direct methods with SHELXS [95], and refined with full-matrix least-squares techniques on $\mathrm{F}^{2}$ with SHELXL [96]. The C-bonded hydrogen atoms were calculated in idealized geometry riding on their parent atoms. In the case of $\mathbf{1}$, fluoride atoms were disordered over two equally occupied positions, while for 3, acetonitrile molecule was disordered over two positions with occupation factor 0.5 . As the crystals structure of compound 2 was already published (FEYTUB, CCDC 1819088) only preliminary data collection was performed to confirm identity [49].

The molecular structure plots were prepared using Diamond (Brandenburg, K. Diamond; Version 4.0; Crystal, Molecular Structure Visualization; Crystal Impact-K. Brandenburg and H. Putz Gbr: Bonn, Germany, 2009).

CCDC-1973604 (1) and CCDC-1973605 (3) contain the supplementary crystallographic data for this paper. These data can be obtained free of charge via http://www.ccdc.cam.ac.uk/conts/retrieving.html (or from the CCDC, 12 Union Road, Cambridge CB2 1EZ, UK; Fax: +44 1223 336033; E-mail: deposit@ccdc.cam.ac.uk).

\subsection{Magnetic Measurement}

The magnetization of powdered samples 1, 2, and 3 was measured over the temperature range 1.8-300 K using a Quantum Design SQUID-based MPMS-XL-5-type magnetometer (San Diego, USA). The superconducting magnet was generally operated at a field strength ranging from 0 to $5 \mathrm{~T}$. Measurements were made at magnetic field 0.5 T. The SQUID magnetometer was calibrated with the palladium rod sample. Corrections were based on subtracting the sample-holder signal and the contribution of $\chi_{D}$ was estimated from the Pascal's constants [97].

\subsection{EPR Spectra}

Electron Paramagnetic Resonance (EPR) spectra of powdered samples 1, 2, and 3 were recorded at room temperature and $77 \mathrm{~K}$ on a Bruker ELEXSYS E $500 \mathrm{CW}$-EPR (continuous-wave EPR) spectrometer (Billerica, MA, USA) operating at X-band frequency and equipped with an ER 036TM NMR Teslameter and E41 FC frequency counter.

\section{Conclusions}

A series of water-soluble and air-stable copper(II) discrete complexes based on 2,9-dimethyl-1,10-phenanthroline (dmphen) and mixed-ligands, containing PTA=O (1,3,5triaza-7-phosphaadamantane-7-oxide), namely $\left[\mathrm{Cu}\left(\mathrm{NO}_{3}\right)(\mathrm{PTA}=\mathrm{O})(\mathrm{dmphen})\right]\left[\mathrm{PF}_{6}\right]$ (1), $\left[\mathrm{Cu}(\mathrm{Cl})\left(\mathrm{dmphen}_{2}\right]\left[\mathrm{PF}_{6}\right](2)\right.$, and $\left[\mathrm{Cu}\left(\mathrm{NO}_{3}\right)_{2}(\mathrm{dmphen})\right](3)$ were synthesized and fully characterized. The solid-state structures of all complexes were determined by single-crystal X-ray diffraction. Compound 1 extended a still poor family of $\mathrm{Cu}$ (II)-based metal-organic architectures assembled from a versatile, water-soluble, and cagelike aminophosphine oxide $(\mathrm{PTA}=\mathrm{O})$. The magnetic susceptibility 
measurements, as well as a relationship between the magnetization and magnetic field strength in 1-3, revealed very weak antiferromagnetic interactions between magnetic centers of copper(II) ions in crystal lattice at low temperature.

Complexes were successfully evaluated for their cytotoxic activities on the normal human dermal fibroblast (NHDF) cell line and the antitumor activity using the human lung carcinoma (A549), epithelioid cervix carcinoma (HeLa), colon (LoVo), and breast adenocarcinoma (MCF-7) cell lines. Complexes 1 and 3 revealed lower toxicity $\left(\mathrm{IC}_{50}\right)$ to normal human cell line $(0.57$ and $1.72 \mu \mathrm{M}$, respectively) than A549 cells ( 0.29 and $0.43 \mu \mathrm{M}$, respectively). Moreover, 3 showed similar activity against HeLa cell line $(0.43 \mu \mathrm{M})$. Complex 2 was more toxic to NHDF cell line in comparison to all cancer lines. These results revealed anticancer potential of new compounds $\mathbf{1}$ and $\mathbf{3}$ and can be a starting point for further surveying of them as a chemotherapeutic agents in cancer treatment. In addition, all tested compounds interacted with human apo-transferrin, causing a conformational change of the protein. Complex 3 showed the most extensive interaction with the loss of helical stability of the protein. The positive values of $\Delta \mathrm{S}^{0}$ and negative $\Delta \mathrm{H}^{0}$ for apo-Tf $-\mathbf{1} / \mathbf{2}$ systems indicated electrostatic interactions, and both positive parameters for 3 revealed hydrophobic and ionic interactions. Moreover, all reactions between copper compounds and human apo-transferrin were spontaneous processes.

Author Contributions: Investigation and conceptualization, E.I.Ś. and P.S.; formal analysis and X-ray analysis, J.K., E.I.Ś., and M.S.; biological analysis, B.B. and U.Ś.-H.; writing—original draft, E.I.Ś and P.S.; writing一review and editing, P.S.; supervision, P.S. All authors have read and agreed to the published version of the manuscript.

Funding: This work was founded by the Narodowe Centrum Nauki program (Grant No. 2012/07/B/ST5/00885 and 2018/29/B/ST5/01418), Poland. The project was partially supported by the Wroclaw Centre of Biotechnology, the Leading National Research Centre (KNOW) for years 2014-2018.

Acknowledgments: We thank. E. Karasińska for her contribution in investigations.

Conflicts of Interest: The authors declare no conflict of interest.

\section{References}

1. Steed, J.W.; Atwood, J.L. Supramolecular Chemistry, 2nd ed.; John Wiley \& Sons, Ltd.: Chichester, UK, 2009; ISBN 978-0-470-51234-0.

2. MacGillivray, L.R. Metal-Organic Frameworks: Design and Applications, 1st ed.; John Wiley \& Sons: Hoboken, NJ, USA, 2010; ISBN 978-0-470-19556-7.

3. Balakrishna, M.S. Copper(I) Chemistry of Phosphines, Functionalized Phosphines and Phosphorus Heterocycles; Elsevier: Waltham, MA, USA, 2019.

4. Zhang, Q.-C.; Xiao, H.; Zhang, X.; Xu, L.-J.; Chen, Z.-N. Luminescent oligonuclear metal complexes and the use in organic light-emitting diodes. Coord. Chem. Rev. 2019, 378, 121-133. [CrossRef]

5. Dumur, F. Recent advances in organic light-emitting devices comprising copper complexes: A realistic approach for low-cost and highly emissive devices? Org. Electron. 2015, 21, 27-39. [CrossRef]

6. Di, D.; Romanov, A.S.; Yang, L.; Richter, J.M.; Rivett, J.P.; Jones, S.; Thomas, T.H.; Abdi Jalebi, M.; Friend, R.H.; Linnolahti, M.; et al. High-performance light-emitting diodes based on carbene-metal-amides. Science 2017, 356, 159-163. [CrossRef] [PubMed]

7. Osawa, M.; Hoshino, M. Highly Efficient OLEDs: Materials Based on Thermally Activated Delayed Fluorescence; Yersin, H., Ed.; Wiley-VCH: Weinheim, Germany, 2019; pp. 119-171. ISBN 978-3-527-69175-3.

8. Thompson, L.K.; Dawe, L.N. Magnetic properties of transition metal (Mn(II), Mn(III), Ni(II), Cu(II)) and lanthanide (Gd(III), Dy(III), Tb(III), Eu(III), Ho(III), Yb(III)) clusters and [nxn] grids: Isotopic exchange and SMM behavior. Coord. Chem. Rev. 2015, 289-290, 13-31. [CrossRef]

9. Nesterov, D.S.; Nesterova, O.V.; Pombeiro, A.J.L. Homo- and heterometallic polynuclear transition metal catalysts for alkane C-H bonds oxidative functionalization: Recent advances. Coord Chem. Rev. 2018, 355, 199-222. [CrossRef]

10. Śliwa, E.I.; Nesterov, D.S.; Kłak, J.; Jakimowicz, P.; Kirillov, A.M.; Smoleński, P. Unique Copper-Organic Networks Self-Assembled from 1,3,5-Triaza-7-Phosphaadamantane and Its Oxide: Synthesis, Structural Features, and Magnetic and Catalytic Properties. Cryst. Growth Des. 2018, 18, 2814-2823. [CrossRef] 
11. Marchetti, F.; Pettinari, C.; Di Nicola, C.; Tombesi, A.; Pettinari, R. Coordination chemistry of pyrazolone-based ligands and applications of their metal complexes. Coord. Chem. Rev. 2019, 401, 213069-213146. [CrossRef]

12. Kirillov, A.M.; Kirillova, M.V.; Pombeiro, A.J.L. Chapter One-Homogeneous Multicopper Catalysts for Oxidation and Hydrocarboxylation of Alkanes. Adv. Inorg. Chem. 2013, 65, 1-31. [CrossRef]

13. Gao, X.; Xu, T.; Jiang, Z.; Yu, H.; Wang, Y.; He, Y. Rational construction and remarkable gas adsorption properties of a HKUST-1-like tbo-type MOF based on a tetraisophthalate linker. Dalton Trans. 2019, 48, 16793-16799. [CrossRef]

14. Gooneratne, S.R.; Buckley, W.T.; Christensen, D.A. Review of copper deficiency and metabolism in ruminants. Can. J. Anim. Sci. 1989, 69, 819-845. [CrossRef]

15. Duncan, C.; White, A.R. Copper complexes as therapeutic agents. Metallomics 2012, 4, 127-138. [CrossRef] [PubMed]

16. Goel, S.; Chen, F.; Cai, W. Synthesis and biomedical applications of copper sulfide nanoparticles: From sensors to theranostics. Small 2014, 10, 631-645. [CrossRef] [PubMed]

17. Duff, B.; Thangella, V.R.; Creaven, B.S.; Walsh, M.; Egan, D.A. Anti-cancer activity and mutagenic potential of novel copper(II) quinolinone Schiff base complexes in hepatocarcinoma cells. Eur. J. Pharm. 2012, 689, 45-55. [CrossRef] [PubMed]

18. Rajalakshmi, S.; Fathima, A.; Rao, J.R.; Nair, B.U. Antibacterial activity of copper(II) complexes against Staphylococcus aureus. RSC Adv. 2014, 4, 32004-32012. [CrossRef]

19. Teguh, H.S.; Fahimah, M. Synthesis of metal-organic (complexes) compounds copper(II)-imidazole for antiviral HIV candidate. Ind. J. Trop. Infect. Dis. 2016, 6, 5-11. [CrossRef]

20. Blockhuys, S.; Wittung-Stafshede, P. Roles of copper-binding proteins in breast cancer. Int. J. Mol. Sci. 2017, 18, 871. [CrossRef]

21. Phillips, A.D.; Gonsalvi, L.; Romerosa, A.; Vizza, F.; Peruzzini, M. Coordination chemistry of 1,3,5-triaza-7-phosphaadamantane (PTA): Transition metal complexes and related catalytic, medicinal and photoluminescent applications. Coord. Chem. Rev. 2004, 248, 955-993. [CrossRef]

22. Bravo, J.; Bolaño, J.; Gonsalvi, L.; Peruzzini, M. Coordination chemistry of 1,3,5-triaza-7-phosphaadamantane (PTA) and derivatives. Part II. The quwst for tailored ligands, complexes and related applications. Coord. Chem. Rev. 2009, 254, 555-607. [CrossRef]

23. Guerriero, A.; Peruzzini, M.; Gonsalvi, L. Coordination chemistry of 1,3,5-triaza-7-phosphatricyclo [3.3.1.1]decane (PTA) and derivatives. Part III. Variations on theme: Novel architectures, materials and applications. Coord. Chem. Rev. 2018, 355, 328-361. [CrossRef]

24. Frost, B.J.; Harkreader, J.L.; Bautista, C.M. Synthesis and solid state structure of Co(II) complexes of O=PTA. Inorg. Chem. Commun. 2008, 11, 580-583. [CrossRef]

25. Martins, L.M.D.R.S.; Alegria, E.C.B.A.; Smoleński, P.; Kuznetsov, M.L.; Pombeiro, A.J.L. Oxorhenium complexes bearing the water-soluble tris(pyrazol-1-yl)methanesulfonate, 1,3,5-triaza-7-phosphaadamantane or related ligands, as catalysts for Baeyer-Villiger oxidation of ketones. Inorg. Chem. 2013, 52, 4534-4546. [CrossRef] [PubMed]

26. Smoleński, P.; Kochel, A. Synthesis of the first Monodentate $S$ - and O-Coordinating 1,3,5-Triaza-7-phosphaadamantane-7-chalcogenides [CoCl(bpy) $\left.{ }_{2}(\mathrm{Z}-\mathrm{PTA}=\mathrm{Z})\right] \mathrm{X}\left(\mathrm{Z}=\mathrm{S}, \mathrm{O} ; \mathrm{bpy}=2,2^{\prime}\right.$-bipyridine; $\left.\mathrm{X}=\mathrm{BF}_{4}, \mathrm{PF}_{6}\right)$ and $\left[\mathrm{CoCl}(\mathrm{bpy})_{2}(\mathrm{~N}-\mathrm{PTA})\right] \mathrm{BF}_{4}(\mathrm{PTA}=1,3,5$-Triaza-7-phosphaadamantane). Polyhedron 2010, 29, 1561-1566. [CrossRef]

27. Śliwa, E.I. Synthesis and structural studies of the new copper(I/II) complexes with organic (P,N) ligands. Master's Thesis, University of Wrocław, Wrocław, Poland, 2014.

28. Jaremko, L.; Kirillov, A.M.; Smoleński, P.; Lis, T.; Pombeiro, A.J.L. Extending the Coordination Chemistry of 1,3,5-Triaza-7-phosphaadamantane (PTA) to Cobalt Centres: First Examples of Co-PTA complexes and of a Metal Complex with the PTA Oxide Ligand. Inorg. Chem. 2008, 47, 2922-2924. [CrossRef] [PubMed]

29. Kirillov, A.M.; Wieczorek, S.W.; Lis, A.; Guedes da Silva, M.F.C.; Florek, M.; Król, J.; Staroniewicz, Z.; Smoleński, P.; Pombeiro, A.J.L. 1,3,5-triaza-7-phosphaadamantane-7-oxide (PTA=O): Nwe diamondoid building block for design of three-dimensional metal-organic frameworks. Cryst. Growth Des. 2011, 11, 2711-2716. [CrossRef]

30. Rancan, M.; Tessarolo, J.; Casarin, M.; Zanonato, P.L.; Quici, S.; Armelao, L. Double Level Selection in a Constitutional Dynamic Library of Coordination Driven Supramolecular Polygons. Inorg. Chem. 2014, 53, 7276-7287. [CrossRef] 
31. Rancan, M.; Tessarolo, J.; Quici, S.; Armelao, L. Post-assembly guest oxidation in a metallo-supramolecular host and structural rearrangement to a coordination polymer. Chem. Commun. 2014, 50, 13761-13764. [CrossRef]

32. Mahmoud, A.G.; Guedes da Silva, M.F.C.; Śliwa, E.I.; Smolenński, P.; Kuznetsov, M.L.; Pombeiro, A.J.L. Copper(II) and Sodium(I) Complexes based on 3,7-Diacetyl-1,3,7-triaza-5 phosphabicyclo [3.3.1]nonane-5-oxide: Synthesis, Characterization, and Catalytic Activity. Chem. Asian J. 2018, 13, 2868-2880. [CrossRef]

33. Ndagi, U.; Mhlongo, N.; Solim, M.E. Metal complexes in cancer therapy - an update from drug design perspective. Drug Des. Devel. 2017, 11,599-616. [CrossRef]

34. Smoleński, P.; Jaros, S.W.; Pettinari, C.; Lupidi, G.; Quassinti, L.; Bramucci, M.; Vitali, L.A.; Petrelli, D.; Kochel, A.; Kirillov, A.M. New Water-soluble polypyridine silver(I) derivatives of 1,3,5-Triaza-7-phosphaadamantane (PTA) with significant antimicrobial and antiproliferative activity. Dalton Trans. 2013, 42, 6572-6581. [CrossRef]

35. Accorsi, G.; Listorti, A.; Yoosaf, K.; Armaroli, N. 1,10-phenanthrolines: Versatile building blocks for luminescent molecules, materials and metal complexes. Chem. Soc. Rev. 2009, 38, 1690-1700. [CrossRef]

36. Silva, T.F.S.; Smoleński, P.; Martins, L.M.D.R.S.; Guedes da Silva, M.F.C.; Fernandes, A.R.; Luis, D.; Silva, A.; Santos, S.; Borralho, P.M.; Rodrigues, C.M.P.; et al. Cobalt and Zinc Compounds Bearing 1,10-phenanthroline-5,6-dione or 1,3,5-tiaza-7-phosphaadamantane Derivatives - Synthesis, Characterization, Cytotoxicity, and Cell Selectivity Studies. Eur. J. Inorg. Chem. 2013, 3651-3658. [CrossRef]

37. Wołoszyn, A.; Pettinari, C.; Pettinari, R.; Badillo Patzmay, G.V.; Kwiecień, A.; Lupidi, G.; Nabissi, M.; Santoni, G.; Smolenński, P. Ru(II)-(PTA) and -mPTA complexes with $\mathrm{N}_{2}$-donor ligands bipyridyl and phenanthroline and their antiproliferative activities on human multiple myeloma cell lines. Dalton Trans. 2017, 46, 10073-10081. [CrossRef]

38. Komarnicka, U.K.; Kozieł, S.; Zabierowski, P.; Kruszyński, R.; Lesiów, M.K.; Tisato, F.; Porchia, M.; Kyzioł, A. Copper(I) complexes with phosphines $\mathrm{P}\left(p-\mathrm{OCH}_{3}-\mathrm{Ph}\right)_{2} \mathrm{CH}_{2} \mathrm{OH}$ and $\mathrm{P}\left(p-\mathrm{OCH}_{3}-\mathrm{Ph}\right)_{2} \mathrm{CH}_{2}$ SarGly: Synthesis, multimodal DNA interactions, and prooxidative and in vitro antiproliferative activity. J. Inorg. Biochem. 2020, 203, 110926/1-110926/14. [CrossRef]

39. Ng, N.S.; Wu, M.J.; Aldrich-Wright, J.R. The cytotoxicity of some phenanthroline-based antimicrobial copper(II) and ruthenium(II) complexes. J. Inorg. Biochem. 2018, 180, 61-68. [CrossRef] [PubMed]

40. Kirillov, A.M.; Smoleński, P.; Haukka, M.; Guedes da Silva, M.F.C.; Pombeiro, A.J.L. Unprecedented Metal-free C(sp3)-C(sp3) Bond Cleavage: Switching from N-alkyl- to N-methyl-1,3,5-triaza-7-phosphaadamantane. Organometallics 2009, 28, 1683-1687. [CrossRef]

41. Jaremko, Ł.; Kirillov, A.M.; Smoleński, P.; Pombeiro, A.J.L. Engineering Coordination and Supramolecular Copper-organic Networks by Aqueous Medium Self-assembly with 1,3,5-Triaza-7-phosphaadamantane (PTA). Cryst. Growth Des. 2009, 9, 3006-3010. [CrossRef]

42. Kirillov, A.M.; Smoleński, P.; Ma, Z.; Guedes da Silva, M.F.C.; Haukka, M.; Pombeiro, A.J.L. Copper(I) Iodide Complexes derived from N-alkyl-1,3,5-Triaza-7-phosphaadamantanes: Synthesis, Crystal Structures, Photoluminescence and Identification of the Unprecedented \{Cu3I5\}2-Cluster. Organometallics 2009, 28, 6425-6431. [CrossRef]

43. Kirillov, A.M.; Filipowicz, M.; Guedes da Silva, M.F.C.; Kłak, J.; Smoleński, P.; Pombeiro, A.J.L. Unprecedented Mixed-Valence $\mathrm{Cu}(\mathrm{I}) / \mathrm{Cu}(\mathrm{II})$ Complex Derived from $\mathrm{N}$-Methyl-1,3,5-triaza-7-phosphaadamantane: Synthesis, Structural Features and Magnetic Properties. Organometallics 2012, 31, 7921-7925. [CrossRef]

44. Mahmoud, A.G.; Guedes da Silva, M.F.C.; Sokolnicki, J.; Smolenński, P.; Pombeiro, A.J.L. Hydrosoluble $\mathrm{Cu}(\mathrm{I})$-DAPTA complexes: Synthesis, characterization, luminescence thermochromism and catalytic activity for microwave-assisted three-component azide-alkyne cycloaddition click reaction. Dalton Trans. 2018, 47, 7290-7299. [CrossRef]

45. Smoleński, P.; Kłak, J.; Nesterov, D.S.; Kirillov, A.M. Unique Mixed-Valence Cu(I)/Cu(II) Coordination Polymer with New Topology of Bitubular 1D Chains Driven by 1,3,5-Triaza-7-phosphaadamantane (PTA). Cryst. Growth Des. 2012, 12, 5852-5857. [CrossRef]

46. Kirillov, A.M.; Smoleński, P.; Guedes da Silva, M.F.C.; Pombeiro, A.J.L. The First Copper Complexes Bearing the 1,3,5-Triaza-7-phosphaadamantane (PTA) Ligand. Eur. J. Inorg. Chem. 2007, 2686-2692. [CrossRef] 
47. Wanke, R.; Smoleński, P.; Guedes da Silva, M.F.C.; Martins, L.M.D.R.S.; Pombeiro, A.J.L. Cu(I) complexes bearing the new sterically demanding and coordination flexible tris(3-phenyl-1-pyrazolyl)methanesulfonate (TpmsPh) ligand and the water-soluble phosphine 1,3,5-triaza-7-phosphaadamantane (PTA) or related ligands. Inorg. Chem. 2008, 47, 10158-10168. [CrossRef]

48. Jaros, S.W.; Sokolnicki, J.; Wołoszyn, A.; Haukka, M.; Kirillov, A.M.; Smoleński, P. Novel 2D coordination network built from hexacopper(I)-iodide clusters and cagelike aminophosphine blocks for reversible "turn-on" sensing of aniline. J. Mater. Chem. C 2018, 6, 1670-1678. [CrossRef]

49. Leandri, V.; Daniel, Q.; Chen, H.; Sun, L.; Gardner, J.M.; Kloo, L. Electronic and Structural Effects of Inner Sphere Coordination of Chloride to a Homoleptic Copper(II) Diimine Complex. Inorg. Chem. 2018, 57, 4556-4562. [CrossRef] [PubMed]

50. Jaros, S.W.; Smoleński, P.; Guedes da Silva, F.C.; Florek, M.; Król, J.; Staroniewicz, Z.; Pombeiro, A.J.L.; Kirillov, A.M.; Guedes da Silva, F.C.; Florek, M.; et al. New silver BioMOFs driven by 1,3,5-triaza-7-phosphaadamantane-7-sulfide (PTA=S): Synthesis, topological analysis and antimicrobial activity. Cryst. Eng. Comm. 2013, 15, 8060-8064. [CrossRef]

51. Nakamoto, K. Infrared and Raman Spectra of Inorganic and Coordination Compounds: Part B: Applications in Coordination, Organometallic, and Bioinorganic Chemistry, 6th ed.; John Wiley \& Sons, Inc.: Hoboken, NJ, USA, 2009; ISBN 978-0-471-74493-1.

52. Nyquist, R.A. Interpreting Infrared, Raman, and Nuclear Magnetic Resonance Spectra? Academic Press: San Diego, CA, USA, 2001; Volume 1-2. ISBN 0-12-523475-9.

53. Frost, B.J.; Lee, W.-C.; Pal, K.; Kim, T.H.; VanDerveer, D.; Rabinovich, D. Synthesis, structure, and coordination chemistry of $\mathrm{O}=\mathrm{PTA}$ and $\mathrm{S}=\mathrm{PTA}$ with 12 metals (PTA = 1,3,5-triaza-7-phosphaadamantane). Polyhedron 2010, 29, 2373-2380. [CrossRef]

54. Addison, A.W.; Rao, T.N.; Reedijk, J.; van Rijn, J.; Verschoor, G.C. Synthesis, structure, and spectroscopic properties of copper(II) compounds containing nitrogen-sulphur donors ligands; the crystal and molecular structure of aqua[1,7-bis(N-methylbenzimidazol-2'-yl)-2,6-dithiaheptane]copper(II) perchlorate. J. Chem. Soc. Dalton Trans. 1984, 1349-1356. [CrossRef]

55. Oliveira, W.X.C.; Pereira, C.L.M.; Pinheiro, C.B.; Lloret, F.; Julve, M. Oxotris(oxalate)niobate(V): An oxalate delivery agent in the design of building blocks. J. Coord. Chem. 2018, 71,707-724. [CrossRef]

56. Ding, C.-F.; Li, X.-M.; Zhu, M.; Xu, H.; Zhang, S.-S. Aquadichloro(2,9-dimethyl-1,10-phenanthroline- $\left.k^{2} N, N\right)$ copper(II). Acta Cryst. Sect. E Struct. Rep. Online 2006, 62, m604-m605. [CrossRef]

57. Zhai, C.-P.; Yan, F.-M.; Zhao, P.-Z. (2,9-Dimethyl-1,10-phenaanthroline--k $\left.{ }^{2} N, N^{\prime}\right)\left(4\right.$-hydroxybenzoato-k $\left.{ }^{2} O, O^{\prime}\right)$ (nitrato-kO)copper(II). Acta Cryst. Sect. E Struct. Rep. Online 2008, 64, m1479. [CrossRef]

58. Marsh, R.E. The perils of Cc revisited. Acta Crystallogr. Sect. B Struct. Sci. 1997, 53, 317-322. [CrossRef]

59. Rajalakshmi, S.; Weyhermuller, T.; Freddy, A.J.; Vasanthi, H.R.; Nair, B.U. Anomalous behavior of pentacoordinate copper complexes of dimethylphenanthroline and derivatives of terpyridine ligands: Studies on DNA binding, cleavage and apoptotic activity. Eur. J. Med. Chem. 2011, 46, 608-617. [CrossRef] [PubMed]

60. Raj, P.; Singh, A.; Singh, A.; Singh, N. Syntheses, crystal and photophysical properties of Cu(II) complexes: Fine tuning of a coordination sphere for selective binding of azamethiphos. Dalton Trans. 2017, 46, 985-994. [CrossRef] [PubMed]

61. Biradha, K.; Fujita, M. Co-ordination polymer containing square grids of dimension $15 \times 15 \AA$ A Journal of the Chemical Society. Dalton Trans. 2000, 21, 3805-3810. [CrossRef]

62. Janiak, C. A critical account on $\pi-\pi$ stacking in metal complexes with aromatic nitrogen-containing ligands. J. Chem. Soc. Dalton Trans. 2000, 3885-3896. [CrossRef]

63. Kahn, O. Molecular Magnetism; VCH: Weinheim, Germany, 1993; pp. 103-134. ISBN 3-527-89566-3.

64. Smart, J.S. Effective Field Theories of Magnetism; W.B. Saunders Comp.: Philadelphia, PA, USA; London, UK, 1966; pp. 139-154. ISBN 978-3-642-70735-3.

65. Carlin, R.L. Magnetochemistry; Springer: Berlin, Germany, 1986; pp. 52-108. ISBN1 101124092226. ISBN2 13 978-1124092225.

66. Cristóvão, B.; Miroslaw, B.; Kłak, J. New mononuclear $\mathrm{Cu}^{\mathrm{II}}$ and tetranuclear $\mathrm{Cu}_{2}^{\mathrm{II}}-\mathrm{La}^{\mathrm{III}}{ }_{2}$ Schiff base complexes-Physicochemical properties. Polyhedron 2013, 62, 218-226. [CrossRef]

67. Cristóvão, B.; Kłak, J.; Miroslaw, B. Synthesis and characterization of $\mathrm{Cu}^{\mathrm{II}}-\mathrm{Ln}^{\mathrm{III}}(\mathrm{Ln}=\mathrm{Ho}, \mathrm{Tm}, \mathrm{Yb}$ or Lu) complexes with $\mathrm{N}_{2} \mathrm{O}_{4}$-donor Schiff base ligand. J. Coord. Chem. 2014, 67, 2728-2746. [CrossRef] 
68. Wałęsa-Chorab, M.; Stefankiewicz, A.R.; Gorczyński, A.; Kubicki, M.; Kłak, J.; Korabik, M.J.; Patroniak, V. Structural, spectroscopic and magnetic properties of new copper(II) complexes with a terpyridine ligand. Polyhedron 2011, 30, 233-240. [CrossRef]

69. Pilbrow, J.R. Transition Ion Electron Paramagnetic Resonance; Oxford Science Publications: Oxford, UK, 1990; pp. 57-150. ISBN1 0198552149. ISBN2 9780198552147.

70. Hathaway, B.J. Copper in Comprehensive Coordination Chemistry, The synthesis, Reactions, Properties and Applications of Coordination Compounds, 1st ed.; Wilkinson, G., Gillard, R.D., McCleverty, J.A., Eds.; Pergamon Press: Oxford, UK, 1987; Volume 5, pp. 533-774. ISBN 0-08-035948-5.

71. Hathaway, B.J. The correlation of the electronic properties and stereochemistry of mononuclear $\left\{\mathrm{CuN}_{4-6}\right\}$ chromophores. J. Chem. Soc. Dalton Trans. 1972, 1196-1199. [CrossRef]

72. Elliott, H.; Hathaway, B.J.; Slade, R.C. The electronic properties of monohalogenobisbipyridyl copper(II) complexes. J. Chem. Soc. A. 1966, 1443-1445. [CrossRef]

73. Procter, I.M.; Hathaway, B.J.; Nicholls, P. The electronic properties and stereochemistry of the copper(II) ion. Part, I. Bis(ethylenediamine)copper(II) complexes. J. Chem. Soc. A 1968, 1678-1984. [CrossRef]

74. Jaros, S.W.; Śliwińska-Hill, U.; Białońska, A.; Nesterov, D.S.; Kuropka, P.; Sokolnicki, J.; Bażanów, B.; Smoleński, P. Light-Stable Polypyridine Silver(I) Complexes of 1,3,5-Triaza-7-Phosphaadamantane (PTA) and 1,3,5-Triaza-7-Phosphaadamantane-7-Sulfide (PTA=S): Significant Antiproliferative Activity of Representative Examples in Aqueous Media. Dalton Trans. 2019, 48, 11235-11249. [CrossRef] [PubMed]

75. Kennt, R.G.; Marmion, C.J. Enhancing the Therapeutic Potential of Platinum-based Anticancer Agents by Incorporating Clinically Approved Drugs as Ligands. In Metal-Based Anticancer Agents, 1st ed.; Casini, A., Vessières, A., Meier-Menches, S.M., Eds.; RSC: London, UK, 2019; p. 23. ISBN 978-1788014069.

76. Konarikova, K.; Frivaldska, J.; Gbelcova, H.; Sveda, M.; Ruml, T.; Janubova, M.; Zitnanova, I. Schiff base $\mathrm{Cu}(\mathrm{II})$ complexes as inhibitors of proteasome in human cancer cells. Bratisl. Med. J. 2019, 120, 646-649. [CrossRef] [PubMed]

77. Jeyalakshmi, K.; Selvakumaran, N.; Bhuvanesh, N.S.P.; Sreekanth, A.; Karvembu, R. DNA/protein binding and cytotoxicity studies of copper(II) complexes containing $N, N^{\prime}, N^{\prime \prime}$-trisubstituted guanidine ligands. RSC Adv. 2014, 4, 17179-17195. [CrossRef]

78. Ganeshpandian, M.; Ramakrishnan, S.; Palaniandavar, M.; Suresh, E.; Riyasdeen, A.; Akbarsha, M.A. Mixed ligand copper(II) complexes of 2,9-dimethyl-1,10-phenanthroline: Tridentate 3N primary ligands determine DNA binding and cleavage and cytotoxicity. J. Inorg. Biochem. 2014, 140, 202-212. [CrossRef]

79. García-Moreno, E.; Gascón, S.; Rodriguez-Yoldi, M.J.; Cerrada, E.; Laguna, M. S-Propargylthiopyridine Phosphane Derivatives as Anticancer Agents: Characterization and Antitumor Activity. Organometallics 2013, 32, 3710-3720. [CrossRef]

80. Wilson, J.J.; Lippard, S.J. In Vitro Anticancer Activity of Cis-Diammineplatinum(II) Complexes with B-Diketonate Leaving Group Ligands. J. Med. Chem. 2012, 55, 5326-5336. [CrossRef]

81. Marouzi, S.; Sharifi Rad, A.; Beigoli, S.; Teimoori Baghaee, P.; Assaran Darban, R.; Chamani, J. Study on effect of lomefloxacin on human holo-transferrin in the presence of essential and nonessential amino acids: Spectroscopic and molecular modeling approaches. Int. J. Biol. Macromol. 2017, 97, 688-699. [CrossRef]

82. Omidvar, Z.; Parivar, K.; Sanee, H.; Amiri-Tehranizadeh, Z.; Baratian, A.; Saberi, M.R.; Asoodeh, A.; Chamani, J. Investigations with spectroscopy, zeta potential and molecular modeling of the non-cooperative behaviour between cyclophosphamide hydrochloride and aspirin upon interaction with human serum albumin: Binary and ternary systems from multi-drug therapy. J. Biomol. Struct. Dyn. 2011, 29, 181-206. [CrossRef]

83. Zhang, H.F.; Yang, G.; Dong, Y.; Zhao, Y.Q.; Sun, X.R.; Chen, L.; Chen, H.B. Studies on the binding of fulvic acid with transferrin by spectroscopic analysis. Spectrochim. Acta Part. A 2015, 137, 1280-1285. [CrossRef]

84. Klajnert, B.; Bryszewska, M. Fluorescence Studies on PAMAM Dendrimers Interactions with Bovine Serum Albumin. Bioelectrochemistry 2002, 55, 33-35. [CrossRef]

85. Ware, W.R. Oxygen Quenching of Fluorescence in Solution: An Experimental Study of the Diffusion Process. J. Phys. Chem. 1962, 66, 455-458. [CrossRef]

86. Groessl, M.; Terenghi, M.; Casinia, A.; Elvirib, L.; Lobinski, R.; Dyson, P.J. Reactivity of anticancer metallodrugs with serum proteins: New insights from size exclusion chromatography-ICP-MS and ESIMS. Anal. Spectrom. 2010, 25, 305-313. [CrossRef] [PubMed] 
87. Rudnev, A.V.; Aleksenko, S.S.; Semenova, O.; Hartinger, C.G.; Timerbaev, A.R.; Keppler, B.K. Determination of binding constants and stoichiometries for platinum anticancer drugs and serum transport proteins by capillary electrophoresis using the Hummel-Dreyer method. J. Sep. Sci. 2005, 28, 121-127. [CrossRef] [PubMed]

88. Garcia, P.F.; Toneatto, J.; Silvero, M.J.; Argüello, G.A. Binding of $\left[\mathrm{Cr}(\text { phen })_{3}\right]^{3+}$ to transferrin at extracellular and endosomal pHs: Potential application in photodynamic therapy. Biochim. Biophys. Acta 2014, 1840, 2695-2701. [CrossRef] [PubMed]

89. Mazuryk, O.; Kurpiewska, K.; Lewiński, K.; Stochel, G.; Brindell, M. Interaction of apo-transferrin with anticancer ruthenium complexes NAMI-A and its reduced form. J. Inorg. Biochem. 2012, 116, 11-18. [CrossRef] [PubMed]

90. Leckband, D. Measuring the Forces That Control Protein Interactions. Annu. Rev. Biophys. Biomol. Struct. 2000, 29, 1-26. [CrossRef] [PubMed]

91. Daigle, D.J.; Pepperman, A.B., Jr.; Vail, S.L. Synthesis of a monophosphorus analog of hexamethylenetetramine. J. Heterocycl. Chem. 1974, 11, 407-408. [CrossRef]

92. Daigle, D.J. 1,3,5-Triaza-7-Phosphatricyclo[3.3.1.13,7]Decane and Derivatives. Inorg. Synth 1998, 32, 40-45. [CrossRef]

93. EN 14476. Chemical Disinfectants and Antiseptics - Quantitative Suspension Test for the Evaluation of Virucidal Activity in the Medical Area-Test Method and Requirements (Phase2/Step 1); European Committee for Standarization: Brussels, Belgium, 2013.

94. Sangster, J. Octanol-water partition coefficients of simple organic compounds. J. Phys. Chem. Ref. Data 1989, 18, 1111-1227. [CrossRef]

95. Sheldrick, G.M. A short history of SHELX. Acta Cryst. 2008, A64, 112-122. [CrossRef] [PubMed]

96. Sheldrick, G.M. Crystal structure refinement with SHELXL. Acta Cryst. Sect. C Struct. Chem. 2015, 71, 3-8. [CrossRef] [PubMed]

97. Bain, G.A.; Berry, J.F. Diamagnetic Corrections and Pascal's Constants. J. Chem. Educ. 2008, 85, 532-536. [CrossRef]

(C) 2020 by the authors. Licensee MDPI, Basel, Switzerland. This article is an open access article distributed under the terms and conditions of the Creative Commons Attribution (CC BY) license (http://creativecommons.org/licenses/by/4.0/). 